Illinois State University

ISU ReD: Research and eData

Theses and Dissertations

$11-26-2018$

\title{
Constructing a Data-based Mortality Profile for Avian Tower Kills at Telecommunication Towers in Illinois
}

Rachel DiPietro

Illinois State University, rayrayd@comcast.net

Follow this and additional works at: https://ir.library.illinoisstate.edu/etd

Part of the Biodiversity Commons, Geographic Information Sciences Commons, Natural Resources and Conservation Commons, and the Natural Resources Management and Policy Commons

\section{Recommended Citation}

DiPietro, Rachel, "Constructing a Data-based Mortality Profile for Avian Tower Kills at Telecommunication Towers in Illinois" (2018). Theses and Dissertations. 1029.

https://ir.library.illinoisstate.edu/etd/1029

This Thesis is brought to you for free and open access by ISU ReD: Research and eData. It has been accepted for inclusion in Theses and Dissertations by an authorized administrator of ISU ReD: Research and eData. For more information, please contact ISUReD@ilstu.edu. 


\title{
CONSTRUCTING A DATA-BASED MORTALITY PROFILE FOR AVIAN TOWER KILLS AT TELECOMMUNICATION TOWERS IN ILLINOIS
}

\author{
Rachel DiPietro
}

74 Pages

During spring and fall seasons, Neotropical migratory passerines travel nocturnally across the Western Hemisphere between their wintering and breeding grounds, often encountering man-made threats. One hazard that has gained considerable publicity in recent decades is the communication tower. While there have been many tower kill studies recorded, there has been no attempt at predicting the risk of towers based on their different attributes (e.g., height, type of light, landscape placement) spatially on a regional scale. The objective of this study was to create seasonal mortality profile maps in GIS for Illinois, based on tower attributes combined with key factors such as bird movement, altitude, and weather patterns as predictors of the set of factors that best determine the avian mortality risk at different towers seasonally throughout the state. Data from previous tower kill studies, compiled into a meta-dataset, was used to determine the relative importance of the various attributes and factors. Principal Component Analyses grouped tower height and land elevation into the first tower factor, and cloud cover, cloud ceiling and percentage of days with $>50 \%$ cloud cover into the first weather factor. Stepwise multiple regressions selected the first tower factor and tower light color for fall, and the first tower factor and wind speed for spring. No interactions were found between stepwise selected factors in ANCOVA analyses. Formulas produced to apply the selected factors to GIS yielded spatial indices of tower mortality risk for towers within coverage of five radars 
for the fall (36\% of total towers) and spring (61\% of total towers). This method is the first attempt at spatially evaluating avian mortality risk at communication towers for any state, and can be refined as an environmental impact assessment to improve safety policies for migratory birds in the communications industry.

KEYWORDS: migration, communication towers, Neotropical migrant birds, mortality, radar, Geographic Information Systems 
CONSTRUCTING A DATA-BASED MORTALITY PROFILE FOR AVIAN TOWER KILLS

AT TELECOMMUNICATION TOWERS IN ILLINOIS

RACHEL DIPIETRO

A Thesis Submitted in Partial

Fulfillment of the Requirements

for the Degree of

MASTER OF SCIENCE

School of Biological Sciences

ILLINOIS STATE UNIVERSITY

2018 
Copyright 2018 Rachel DiPietro 
CONSTRUCTING A DATA-BASED MORTALITY PROFILE FOR AVIAN TOWER KILLS

AT TELECOMMUNICATION TOWERS IN ILLINOIS

RACHEL DIPIETRO

COMMITTEE MEMBERS:

Angelo P. Capparella, Chair

John C. Kostelnick

Steven A. Juliano 


\section{ACKNOWLEDGMENTS}

This project would not have been possible without the feedback and support of several individuals. Within Illinois State University, I would like to thank my committee: Dr. Angelo Capparella, Dr. Steven Juliano, and Dr. John Kostelnick, for their guidance. I thank Dr. Bill Perry for assistance in assembling the R code to predict corrected reflectivity values and Dr. Byers for statistical feedback. I would also like to thank my family and friends for their unwavering support, and thanks be to God for His provisions and grace throughout the project.

I would like to thank Dr. Joelle Gehring of the Federal Communications Commission (FCC) for providing the tower point data used in spatial analyses and providing extensive background on tower specifications and the steps taken by the FCC and Federal Aviation Administration (FAA) to make more bird-safe tower improvements over the years. Various tower engineers throughout Illinois were also directly contacted for information on historic and current tower attributes. I would especially like to thank within the communications field, Mitch Hopper and Doug Quick, both of whom have decades of experience in Illinois broadcasting history between them, for providing information on older or now-nonexistent towers. Vernon Kleen of Lincoln Land Community College, Dr. David Horn of Millikin University, Dr. David Bohlen of the Illinois Natural History Survey (INHS), and Dr. Richard Graber of the INHS also provided specimen data from outside the literature. I would further like to thank Dr. Ron Larkin of the INHS for feedback.

This project was also made possible by several authors of tower kill reports from outside Illinois. In particular, I would like to thank Dr. Travis Longcore of Urban Wildlands for providing feedback on the application of his meta-analysis to my thesis. Drs. Robert Crawford and Todd Engstrom of Florida State University also provided personal data, gathered by Herbert 
Stoddard, Sr., at a tower site in Florida over several decades. Further thanks goes to Joey Herron of Jane Lewe, WV, Ronnie Barkley of Goodland, KS, John Palmquist of Lindberg, KS, Jenny Nehring of Monte Vista, CO, Sandy Bivens of Nashville, TN, Dr. Eugene Young of Northern Oklahoma University, and Dr. Charles Nicholson of the Tennessee Valley Authority (retired) for providing field notes and data from tower kill reports to complete the tower kill datasets used in the project.

Funding Statement: This project was funded by a grant from the Illinois Ornithological Society. The grant funder did not have input into the content of the manuscript or require approval of the manuscript upon completion.

Author Contributions: Special acknowledgement also is due to Dr. Jeffrey Buler and Jaci Smolinsky of the Aeroecology Laboratory at the University of Delaware for their collaboration in using their software and processing methods for selecting, filtering and cleaning radar data to be suitable for spatial analyses in ArcGIS.

R. D. 


\section{CONTENTS}

\section{Page}

ACKNOWLEDGMENTS

CONTENTS

iii

TABLES

vi

FIGURES

vii

CHAPTER I: INTRODUCTION 1

Neotropical Passerine Migration 1

Tower Kills 2

Conservation Status and Implications $\quad 5$

Tower Location Analysis in GIS and Comparisons to Scientific Literature 9

Advances in Tracking Bird Migration 11

$\begin{array}{ll}\text { Objectives } & 12\end{array}$

$\begin{array}{ll}\text { Hypotheses } & 13\end{array}$

CHAPTER II: METHODS 14

$\begin{array}{ll}\text { Tower Data Compilations } & 14\end{array}$

Temporal and Spatial Project Scope 15

Historical Data Analysis $\quad 16$

Spatial Data and Processing 17

$\begin{array}{ll}\text { Towers } & 17\end{array}$

$\begin{array}{ll}\text { Weather } & 18\end{array}$

Analysis of Bird Movements with NEXRAD 19

Evaluation of Tower Mortality Risk in Illinois $\quad 22$ 
$\begin{array}{ll}\text { CHAPTER III: RESULTS } & 25\end{array}$

$\begin{array}{ll}\text { Principal Component Analysis } & 25\end{array}$

$\begin{array}{ll}\text { Stepwise Multiple Regression } & 26\end{array}$

$\begin{array}{ll}\text { ANCOVA } & 26\end{array}$

$\begin{array}{ll}\text { Analysis of Bird Movements with NEXRAD } & 27\end{array}$

Evaluation of Tower Mortality Risk in Illinois 27

$\begin{array}{ll}\text { CHAPTER IV: DISCUSSION } & 29\end{array}$

Compilations of Historic Tower Kill Reports 29

$\begin{array}{ll}\text { Principal Component Analysis } & 30\end{array}$

$\begin{array}{ll}\text { Stepwise Multiple Regression } & 31\end{array}$

$\begin{array}{ll}\text { ANCOVA } & 33\end{array}$

Analysis of Bird Movements with NEXRAD 33

Evaluation of Tower Mortality Risk in Illinois 35

$\begin{array}{ll}\text { Conclusions } & 38\end{array}$

$\begin{array}{ll}\text { Future Directions } & 38\end{array}$

$\begin{array}{lr}\text { REFERENCES } & 40\end{array}$

APPENDIX A: CORRECTION FACTORS FOR CALCULATING MAXIMUM AND

MEAN SEASONAL TOWER MORTALITY 52

APPENDIX B: RADAR STATIONS USED IN BIRD MOVEMENT ANALYSIS 53

APPENDIX C: WEATHER STATIONS USED IN KRIGING INTERPOLATIONS 54

APPENDIX D: SOURCES AND LINKS FOR GIS SPATIAL DATA 56

APPENDIX E: ANOMALOUS SAMPLING TIMES USED FOR EASTERN UNITED

STATES TOWER WEATHER 
APPENDIX F: ANOMALOUS SAMPLING TIMES USED FOR ILLINOIS TOWER

WEATHER 


\section{TABLES}

Table

Page

1. Eigenvalues for Eastern United States Tower Principal Component Analysis

2. Rotated Factor Patterns for Eastern United States Tower Principal Component Analysis

3. Eigenvalues for Eastern United States Weather Principal Component Analysis

4. Rotated Factor Patterns for Eastern United States Weather Principal Component Analysis

5. Eigenvalues for Illinois Tower Principal Component Analysis

6. Rotated Factor Patterns for Illinois Tower Principal Component Analysis

7. Eigenvalues for Illinois Weather Principal Component Analysis

8. Rotated Factor Patterns for Eastern United States Weather Principal Component Analysis

9. Stepwise Selection Summary for Eastern United States Towers, Fall

10. Stepwise Multiple Regression Parameter Estimates for Eastern United States

Towers, Fall

11. Stepwise Selection Summary for Eastern United States Towers, Spring

12. Stepwise Multiple Regression Parameter Estimates for Eastern United States Towers, Spring

13. Stepwise Selection Summary for Illinois Towers, Fall

14. Stepwise Multiple Regression Parameter Estimates for Illinois Towers, Fall

15. Stepwise Selection Summary for Illinois Towers, Spring

16. Stepwise Multiple Regression Parameter Estimates for Illinois Towers, Spring 


\section{FIGURES}

Figure

1. Examples of Weather Stations and Kriging Interpolation in ArcGIS 64

2. Seasonal Classified Densities for Seven Radar Stations Covering Illinois 65

3. Log Mean Mortality of Eastern United States Towers, Fall 66

4. Log Mean Mortality of Eastern United States Towers, Spring 67

5. Corrected Residuals for Mean Reflectivity (MN) of Five Radars in Illinois 68

6. Avian Mortality Risk Index for Towers Within Coverage of Five Illinois Radars in

$\begin{array}{ll}\text { Fall } & 69\end{array}$

7. Avian Mortality Risk Index for Towers Within Coverage of Five Illinois Radars in

$\begin{array}{ll}\text { Spring } & 70\end{array}$

8. Detail of Avian Mortality Risk Indices for Previously Studied Towers in Central

Illinois in Fall and Spring $\quad 71$

9. Statewide Views of Data-deficient Areas for Illinois Tower Mortality Indices in Fall

$\begin{array}{ll}\text { and Spring } & 73\end{array}$

10. Simple Regression of Log-transformed Means for Historic Fall Tower Kills in Illinois and Calculated Values of $M$ 


\section{CHAPTER I: INTRODUCTION}

\section{Neotropical Passerine Migration}

Neotropical migrants encompass a broad group of birds that include passerines, waterfowl, shorebirds and raptors, though the taxa most relevant to this study are passerines, including tyrant flycatchers (Tyrannidae), wood warblers (Parulidae), thrushes (Turdidae), vireos

(Vireonidae), and blackbirds (Icteridae). In the spring and fall, they travel distances of often thousands of miles between their breeding grounds in the temperate zones of the United States and Canada, and their wintering grounds in tropical Central and South America, Mexico, and the Caribbean. During fall migration, many birds funnel down through the Mississippi Flyway in high concentrations, stopping over along the coast before crossing or going around the Gulf of Mexico; a smaller number of birds will travel over land around the Gulf of Mexico (Moore et al. 1990). On northward journeys in the spring, staging areas such as the cheniers and barrier islands along the Gulf Coast, and the freshwater marshes and islands of Lake Erie, become critical stopover points for Neotropical migrants, many of which fly directly back to North America across the Gulf of Mexico (Ewert et al. 2005, Moore et al. 1990). In both seasons, Neotropical migrant passerines migrate through the night, at altitudes of 700 to 800 meters, using the moon and the stars to help them navigate (Moore 1987, Kerlinger and Moore 1989, Gauthreaux and Belser 2006). The state of Illinois, however, being landlocked and further north from the staging areas of the Gulf Coast and most of the Great Lakes, experiences a more broad-front pattern of migration in both fall and spring (Graber 1968). 


\section{Tower Kills}

There are many natural and human-made hazards that migratory birds must overcome on their journey to or from their breeding grounds, some of which can disorient birds and result in their deaths. One human-made obstacle that has gained significant public attention, due to its prolific presence across the landscape to meet burgeoning technological demands, is the communication tower (Hufford 2001). A recent review estimates that $\sim 6-7$ million birds are killed by collisions with communication towers each year in the United States and Canada, compared with nearly 590,000 per year for wind turbines across the same regions (Loss et al. 2015).

Causes for nocturnal tower collisions are well-known. Nocturnal migrants are disoriented by aircraft warning lights on large towers, often being lured in to circumnavigate the towers, where they fly into guy wires suspending a tower in place and fall, or die of fatigue from circling the tower (Avery et al. 1976, Gauthreaux and Belser 2006). Chances of collision with a tower or its guy wires are much greater on nights with little or no moonlight, extensive cloud cover and low cloud ceiling (e.g. Larkin and Frase 1988). Previous studies have demonstrated that the greatest tower mortality during fall migration is during nights with winds blowing from north to south with over 50\% cloud cover (Avery et al. 1977), a low cloud ceiling within $550 \mathrm{~m}$ of the ground which forces migrating birds to fly at lower altitudes (Seets and Bohlen 1977), and with large numbers of birds travelling along north-to-south cold fronts (Tanner et al. 1954). Larkin and Frase (1988) detected a sharp change in wind direction from NNW to S with the arrival of overcast cloud cover over their studied tower site, which likely could have blown in a large number of birds before an abrupt change to a headwind impeded their travel and kept them within range of the tower. Weather factors contributing to tower kill risk during the spring have been more variable. Most spring studies indicate similar factors to those of fall, such as overcast 
skies, sometimes accompanied by precipitation (e.g. Brewer and Ellis 1958, Laskey 1967). Wind direction varies from northerly headwinds to southerly tailwinds in spring (Boso 1965), but a previous thesis study in Wisconsin by Kruse (1996) indicated that most birds travel with the passage of maritime fronts moving from south to north.

There is evidence that some colors and steadiness of warning lights are more hazardous than others; in particular, towers with steady or flashing red lights have more casualties than towers with strobing white lights (Gehring et al. 2009). Strobing means a bright, abrupt light with a long interval before the next light, during which the light goes completely off. Flashing involves a softer light gradually fading brighter and darker, with a shorter interval between flashes, and the light does not go completely off at the darkest point but remains visible. Additionally, two studies support the hypothesis that longer wavelengths of light, especially yellow and red, can interfere with birds' flight orientation. Birds flew in a consistent direction while under blue, white or green light, but their flight paths became scattered under yellow or red light, all tested separately (Wiltschko et al. 1993, Wiltschko and Wiltschko 1999). These differences in color and flash time could likely account for why mortality is lower around towers with white strobes than towers with red flashing or steady-burning lights. Preliminary studies indicate that towers lit with both flashing and steady-burning red lights had significantly higher mortality rates than towers lit with only red flashing or white strobing lights, and that bird mortality at towers can be reduced by as much as $50-71 \%$ by extinguishing steady-burning red lights and only operating flashing lights (Gehring et al. 2009). Unfortunately, due to tower operator concerns over the expense of transitioning to more bird-safe lighting systems and because Federal Communications Commission (FCC) bird-friendly policies remain as 
recommendations rather than requirements, the strategy of extinguishing steady-burning lights has not been universally applied (Dr. Joelle Gehring, FCC, personal communication).

Among the scientific documentation of tower kills in the United States are several studies of interest for the state of Illinois. One of significance for the central Illinois region occurred near Springfield, on September 16-17, 1980 at the Channel 20 WCIS tower in Sangamon County. The night on which the kill occurred, a cold front was passing through the area from the north, bringing rain and clouds with a ceiling as low as $183 \mathrm{~m}$ that obscured any moonlight and stars. The kill was composed of 240 individuals from 35 species, of which 160 individuals and 19 species were parulids. Ovenbirds (Seiurus aurocapilla) had the highest number of casualties at 59 individuals (Bohlen 1980). The Ovenbird was also among the most common casualty in a series of large kills from September 2-29, 1972 at seven tower sites examined in central Illinois, with a total of 691 individuals out of 4,651 birds recorded from all species documented (Seets and Bohlen 1977). Lundstrom et al. (2013) recorded that of 415 individual birds found under three towers studied in central Illinois, 272 (66\%) were parulids.

A deficiency with scientific reports of most tower kills is that since the first communication towers were erected in the 1940s and 1950s, reports have been sporadic and have not conformed to a single methodology. Most of these studies have also only spanned the course of a few days at a time during a single migration season, so recorded casualties are likely a small fraction of the actual death toll across a region during the season in question. Additionally, studies are typically performed in the mornings following a major kill of nocturnal migrants, if specimen collection time is documented at all, and birds that have been taken by nocturnal predators or scavengers are not accounted for (Shire et al. 2000). 
While tower kills are a hazard to migratory birds, one ironic positive is that they can provide large quantities of data on migratory species that are more difficult to obtain from tracking live individuals. From salvaged specimens, information on a species, such as age and sex ratio demographics, migration timing for different demographics, individual physical fitness represented by fat index at time of the kill, geographical migration patterns, and areas of migratory concentration can be obtained (Brewer and Ellis 1958). Tower kills can also be a possible indicator of population trends for different species; some long-term studies have found a correlation between the proportion of species and individuals killed at towers and current survey data (Neisslie et al. unpublished manuscript).

\section{Conservation Status and Implications}

Shire et al. (2000) reports that of 47 detailed historical studies of tower kills, a total of 184,797 birds belonging to 230 species were killed before the year 2000 and $17.8 \%$ were parulids. The 230 species documented in this comprehensive study represents about a quarter of all bird species in the United States. About one in five of these species is listed on either the United States Fish and Wildlife Service's (USFWS) Species of Management Concern List, or the Partners in Flight's (PIF) peer-reviewed Watch List of the top 100 birds of conservation concern after those protected by the Endangered Species Act. The PIF list was produced by a coalition of conservation organizations, federal and state entities, academic institutions and private sector corporations (Shire et al. 2000). Of the 41 parulid species included in Shire et al.'s analysis, 12 are on either the USFWS Species of Management Concern List, the PIF Watch List, or the USFWS Endangered Species List (Shire et al. 2000). This approximately one in four species ratio indicates that the declining species of parulids are among the birds most impacted by tower kills. 
A more recent review of North American Breeding Bird Survey (BBS) data provides a thorough description for trends of many Neotropical migrant species. Overall, BBS data found declines in 133 species of Neotropical migrants from 1968 to 2011. Among these, 17 parulid species, Veery, Swainson's and Wood Thrushes, Dickcissel, Indigo Bunting, eastern Rosebreasted Grosbeak, and 11 of 18 blackbird species had significant population declines (Sauer et al. 2013). Longcore et al. (2013) found in their meta-analysis of tower kills across North America that 13 of the 20 species killed most frequently by population percentage were listed as either federally Endangered or American Bird Conservancy Birds of Conservation Concern.

Migration periods have been shown to be the most dangerous and energetically-taxing times of passerine birds' lives. A study focusing on a priority species, the Black-throated Blue Warbler (Setophaga caerulescens), found surveyed survivorship percentages in summer and winter to consistently be in the mid- to upper 90s, while spring and fall migration were just 6575\% (Sillett and Holmes 2002). In an analysis of BBS data examining population trends of 62 Neotropical migrant bird species comparing the time periods of 1966-1978 and 1978-1987, 41 of the 62 species showed significant population declines during 1978-1987, while only 15 of these same species showed declines in 1966-1978. Of the 41 species showing declines in 1978-1987, 20 were significant, ranging from $0.7 \%$ to $15.8 \%$. By comparison, significant declines in shortdistance migrant species ranged from $1.2 \%$ to $2.8 \%$ during $1978-1987$, and the only significant decline in permanent resident species during 1978-1987 was a $1.4 \%$ decline in the House Sparrow (Passer domesticus) (Robbins et al. 1989). Coupled with a short life expectancy of no more than 5-6 years, many passerines are therefore vulnerable to several threats along their migration, including a significant number that are human-caused. Communication tower collisions in and of themselves are not a top killer, ranking behind predation by cats (2.6 billion), 
building collisions (624 million), and automobiles (213 million) in terms of annual estimates in the United States and Canada (Loss et al. 2015), but they can result in considerable cumulative long-term effects on bird populations when combined with these more dangerous hazards. This ranking of top mortality causes is for birds as a whole, and so does not include assessment of individual species for which the rankings could be different.

Neotropical migrant passerines are integral ecosystem components from a conservation perspective. Insect-eating species play a critical role in maintaining forest ecosystem health by preventing insect outbreaks, and can act as mesopredators in trophic cascades with herbivorous insects and plants, regardless of whether the ecosystem is natural or agricultural (Mäntalyä et al. 2011). They can also provide the ecological service of agricultural pest control, with several notable examples involving crops that have significant value to humans. One bird exclusion experiment on Blue Mountain shade coffee plantations in Jamaica found that in plots where Black-throated Blue Warblers and other insectivorous birds were allowed to forage, insect infestations of coffee fruits were $1-14 \%$ lower than in plots where birds were excluded. This effect yielded an increase in good fruit crops valued at 62-2,344 USD/farm, or 44-105 USD/ha (Kellerman et al. 2008). Birds can also reduce the impact of insect pests on corn; one study found that cutworm and weevil pests were significantly higher in corn plots where birds were excluded (Tremblay et al. 2001). Leaf damage to cacao plants in another exclusion experiment was significantly greater in plots where birds were excluded (Van Bael et al. 2007). Wine-grape growers have also benefitted from the presence of birds; roughly 2.4 times more liver beet armyworms were removed from vineyard plots that had experimental nest boxes for Western Bluebirds (Sialia mexicana) than in plots without nest boxes (Jedlicka et al. 2011). While birds are also capable of contributing direct or indirect disservices to agroecosystems, such as 
granivory, frugivory or predation of natural enemies to other pests, excluding birds from such environments while ignoring the total net effects of birds can escalate both environmental damage and habitat loss for many species both inside and outside the agroecosystem (Bennett et al. 2009, Peisley et al. 2016). Neotropical migrant passerines are also important agents of seed dispersal. A survey of fecal samples from 1,016 individuals of 30 Neotropical migrant species on their wintering grounds found seeds from as many as 63 different species of tropical plants. This level of diversity likely rivals the seed dispersal ability of some resident Neotropical birds (Blake and Loiselle 1992). These birds can also support economic growth of the ecotourism industry. The United States Fish and Wildlife Service estimated that as of 2011, nearly \$41 billion is spent annually on expenses related to birding, including travel and lodging, food, local tourism services, and wildlife viewing supplies. Additionally, 666,000 new jobs were created from these expenditures either directly in the form of wildlife viewing, or indirectly in the manufacturing and selling of supplies and services to birders. These services produced $\sim 107$ billion USD in total industry output (Carver 2013). Overarching these benefits of Neotropical passerines is that birds in general are ubiquitous and serve as noticeable and valuable ecological indicators. Birds can be readily sampled and have a well-known taxonomy compared to other taxa (Scheffers et al. 2012), are easily affected by habitat destruction or disturbance (Askins and Philbrick 1987), can occupy high trophic levels and can therefore reflect problems at lower trophic levels (Sample et al. 1993). Additionally, their community composition can reflect interspecific interactions and population trends of many species (Cody 1981). If bird populations or species composition are in decline, it is likely a sign of the cumulative effects of human-caused mortality sources, including tower collisions (Neisslie et al. unpublished manuscript). 
Studies showing the importance of migratory birds have become more vital relative to the current interpretation of the Migratory Bird Treaty Act (MBTA). Provisions in the MBTA that require disciplinary action for failure to mitigate for incidental take in permitted activities (i.e., any instance where bird deaths are not intended, but are to be expected) are no longer being enforced (Department of the Interior 2018), resulting in less pressure on sectors like the communications industry to implement more bird-safe measures in their operations. Determining how much of the tower kill risk centers around features pertaining to towers themselves will therefore be critical to provide incentive for communication tower owners to modify towers to lower risk to birds in the absence of rigorous law enforcement.

\section{Tower Location Analysis in GIS and Comparisons to Scientific Literature}

Resources are available that allow for all known communication towers within a certain region to be mapped. Knowing the locations of all towers provides an advantage in assessing how many towers in the respective region have actively been studied in the scientific literature, clarifying how extensively the tower kill problem has been studied and what areas need more attention to understand the severity of the problem. The Antenna Structure Registration database within the FCC lists 3,718 communication tower structures classified as either tower, guyed tower or lattice structure for the state of Illinois as of 2016. However, only 13 towers have received scientific attention within the state, with most $>240 \mathrm{~m}$, and all in a roughly linear pattern across central Illinois (Brewer and Ellis 1958, Cochran and Graber 1958, Parmalee and Parmalee 1959, Petersen 1959, Parmalee and Thompson 1963, Seets and Bohlen 1977); this also leaves only half of the 24 towers taller than $240 \mathrm{~m}$ documented in 2010 having been studied. One of the $>240 \mathrm{~m}$ height class towers studied does not exist anymore, as the WJJY tower in Bluffs, IL, one of seven tower sites studied in Seets and Bohlen (1977), was blown down in an ice storm in 1978 
(J. Mitch Hopper, former Assistant Chief Engineer of WRSP-TV and former Chief Engineer of WVEM-FM, both in Springfield, IL; personal communication). The same ice storm also destroyed the original WAND-TV tower with red lights in Argenta, IL (Doug Quick, broadcaster and anchor, personal communication), and a new tower with white lights instead of red was built in its place. Most existing studies are $40-50$ years old, meaning the results of these tower kill analyses in terms of species and individual counts most likely do not reflect the current environment or differential population declines in terms of tower numbers, heights and kills across the state. Some national estimates of tower fatalities for birds in the United States have used as few as three (Banks 1979) and seven (Avery et al. 1980) towers total, and the same could be done using roughly a dozen towers in the state of Illinois. However, for the purposes of this project, several tower studies from outside of Illinois are used to increase sample size and provide greater variation of tower kill conditions to gauge the most likely factors that contribute to major kills.

This study therefore required the use of GIS data for all tower sites in the state of Illinois. All parameters deemed significant by previous studies are accounted for with current spatial data, including bird movement from NEXRAD radar files (National Oceanic and Atmospheric Agency), weather conditions including wind speed, wind direction, cloud cover, cloud ceiling altitude (NOAA), percentages of days with $>50 \%$ cloud cover and favorable winds, and tower attributes including height above ground level (AGL), color and numbers of steady-burning or flashing lights (strobing for white color), and number of guy wire sets (Federal Communications Commission, Illinois tower data courtesy of Dr. Joelle Gehring). 


\section{Advances in Tracking Bird Migration}

Birds have been detected on radar since that technology was first introduced around World War II, where mass movements of birds were first referred to as "angels" (Lack and Varley 1945, Buss 1946). With the advancement of Next Generation Radar (NEXRAD) in the early 1990's, detection by radar of birds and other biological targets such as bats and insects has become more efficient, and many biologists now use radar to track animal movements on a regional scale (Gauthreaux and Belser 2003). Bird movements sampled close to dawn or dusk allow evaluation of stopover habitat use by nocturnal migrants (Buler and Dawson 2014). There have been previous attempts to characterize the density of bird migration over a given region and time period into hotspots (Schools et al. 2012). However, due to range biases and inaccuracy of measured bird movements caused by poor overlap with radar beam heights, more refined methods of cleaning radar scans and eliminating inherent flaws of radar study are needed to gain a better understanding of how and where birds move during their time aloft.

A resource made available to the public in 2017 to help protect declining birds is an app called Songbird Saver (songbirdsaver.org). This app is available in desktop and mobile formats, and allows users to find communication towers relative to major migratory flyways and designated Important Bird Areas on maps of the United States. The app provides the address, phone and email contact information for each tower site, allowing users to contact their local tower operators and inform operators of the problem communication towers pose to migrating birds during the spring and fall. This platform empowers concerned citizens to take action and raise awareness of the issue, even as the scientific understanding behind the extent of the tower kill problem is incomplete. 
In spring of 2018, the Cornell Lab of Ornithology launched BirdCast (birdcast.info), a three-day forecast that combines precipitation and expected bird movements on a weather map of the continental United States. This new platform is a valuable tool that allows the public to see in real time how birds are predicted to move during spring and fall migration seasons, and could potentially allow tower operators to take precautions, (e.g., extinguishing outdoor security lights to lessen the impacts of the towers) ahead of nights of predicted heavy bird movement to reduce nighttime hazards to migrating birds. Potential future resolutions to reduce bird collisions include the use of Aircraft Detection Lighting Systems (ADLS), which implement motion sensors to turn tower warning lights on only during close-range flyby of aircraft. However, there has so far been no attempt at producing a seasonal profile of bird mortality risk on a regional scale based on radar data that has been summarized over a specified study period.

\section{Objectives}

There were two main objectives to this project. The first objective was to formulate a novel analysis of mortality parameters from historic tower kill reports on both the scale of Illinois and the eastern United States. These two compilations were compared to determine which parameters best predict the tower kill risk throughout the state. The second objective was to test the statistical significance of each tower mortality parameter as a weighting of the same current parameters in ArcGIS to evaluate the seasonal kill risk based on recent spring and fall migration periods in Illinois, September 1 - October 31, 2016 and April 1 - May 31,2017. This was visualized by maps detailing the level of tower kill risk for those two migration seasons. 


\section{Hypotheses}

This study tested a set of robust hypotheses which state that bird mortality will be greatest under the combined following conditions: when communication towers are over $350 \mathrm{~m}$ tall with a high number of guy wire sets (one set being defined as three wires each separated by $120^{\circ}$ for tripodal support of the tower), they have red steady-burning lights (Gehring et al. 2009), and weather conditions consist of an extensive cloud cover and a low cloud ceiling (Larkin and Frase 1988).

Distributions of bird migration density is hypothesized to be homogeneous across the state due to broad-front travel patterns and distance from major migration staging areas near large bodies of water (Graber 1968); therefore, the determining factors for mortality are expected to be prevailing weather conditions and parameters of towers along migration routes. Analysis of bird densities in fall and spring is therefore predicted to yield no significant hotspots with the exception of the Lake Michigan shoreline. 


\section{CHAPTER II: METHODS}

\section{Tower Data Compilations}

Data for all known tower kills was compiled for the state of Illinois. The same procedure was used for a second compilation expanding the range of tower kill reports to include the eastern United States (defined as the entire region east of the Mississippi River in addition to selected states west of the Mississippi with documents towers kills, such as Iowa, Kansas, North Dakota and Minnesota), for which Illinois data was a subset. Sources for avian kill data include published scientific articles, online specimen and museum records, and personal communication with authors. Complete lists of kill data with all measured parameters by season (fall or spring) and region (eastern United States or Illinois) are in Tables S1-S4. To calculate the most accurate estimates for maximum mortality and mean annual mortality for the duration of each study, correction factors were applied if included by authors in the original publications. A full list of correction factors is in Appendix A. Google Earth was used to perform visual searches to locate towers and their registration information in the FCC's Antenna Structure Registration online database. Where historic tower attributes did not match current records, or FCC records could not provide sufficient information, television station personnel, research authors, or local tower operators with knowledge of historic tower sites (Mitch Hopper and Doug Quick, personal communication) were contacted to obtain information on tower attributes, particularly the number of guy wire sets, lighting color, and numbers of steady-burning and flashing lights. Additionally, the FAA Advisory Circular, FCC lighting and marking regulations, and visual guides based on FAA requirements were used to augment data on tower lighting. Weather data for dates of bird kills was obtained using the application router for the National Oceanic and Atmospheric Administration's (NOAA's) hourly surface observations, except in cases where 
there were temporal or geographical deficiencies in NOAA's archives. Weather data for most tower sites was found using this database. However, there were 7 of 39 tower records in the eastern United States compilation and 4 of 16 tower records in the Illinois compilation that were located far from major airports or weather stations, so no NOAA data were available. For one of these towers in the eastern United States compilation and two towers in the Illinois compilation, weather data were obtained from literature descriptions if records from the nearest station did not have weather for some of the older kill dates. Weather data could not be obtained for the remaining towers in the two compilations. Consequently, the final dataset still included some tower kill reports which had null entries for some or all of the weather parameters.

The tower compilations were separated by two tabs for fall and spring kills. For each tower entry, the maximum annual mortality, mean annual mortality and standard deviation were calculated. In cases where tower kill numbers by year were not provided in published reports, authors were contacted directly for year by year breakdowns of kill numbers. Parameters included for each entry were: latitude and longitude coordinates, land elevation, structure height, number of guy wire sets, number of steady lights, number of flashing lights, light color, averages for wind speed, wind direction, cloud cover and cloud ceiling, percentages of days during each study period with favorable wind directions and percentages of days during each study period with at least $50 \%$ cloud cover.

\section{Temporal and Spatial Project Scope}

The temporal scope of the project encompasses two recent fall and spring migration events, September 1 - October 31, 2016 and April 1 - May 31, 2017, respectively. These date ranges were chosen, rather than having spring and fall migration events in the same calendar year, to ensure consistency in the same generation of birds during both migration events. All weather and 
radar data collected for the project were limited to these two seasons. The state of Illinois was the spatial scale. Radar and weather stations used from Illinois and adjacent states are in Appendices $\mathrm{B}$ and $\mathrm{C}$.

\section{Historical Data Analysis}

Once compiled, statistics for the two tower kill report compilations were analyzed using Principal Component Analysis (PCA), stepwise multiple regression and ANCOVA in SAS software (SAS Institute Inc., 2013). PCAs were used to determine the importance of the quantitative tower parameters (elevation, tower height, number of guy wire sets, number of steady lights, and number of flashing lights) and weather parameters (average wind speed, average wind direction, average cloud cover, average cloud ceiling, percentage of days within the study period with favorable wind direction, and percentage of days studied with at least $50 \%$ cloud cover) in the variation expressed in the maximum and mean seasonal mortality observed at each tower. For each of the two compilations, the spring and fall data were combined back into larger sample sets for the PCA. Tower parameters assigned eigenvalues $\geq 1.0$ were kept, and those with eigenvalues $<1.0$ were discarded for the remainder of the analysis, although exceptions were made for eigenvalues close to 1 on scree plots (i.e., $~ 0.99$ ). PC scores for all historic tower kill reports are in Tables S5-S8.

Stepwise multiple regressions, using the stepwise linear model analysis with the GLM SELECT procedure in SAS software, were used to select significant Principal Component (PC) factors based on the calculated $\log$ of mean kills +1 for the eastern United States and Illinois by season. Log means were plotted and set to trendlines to determine the relationship between significant factors selected for kill risk. 
PC scores selected by the stepwise multiple regression were tested using ANCOVA to determine whether there was an interaction between tower light color (a class variable) and the selected tower and weather factors. Separate ANCOVA tests were done for the eastern United States and Illinois, and by season.

\section{Spatial Data and Processing}

The most current spatial data were used to measure tower kill parameters in ArcGIS. A full list of the spatial data sources and other pertinent information is in Appendix D. All spatial data were uploaded into ArcMap (ESRI 2013) as either vector (shapefile) or raster (grid) data. Each data type required varying degrees of additional processing before analysis. All data were overlaid onto a base layer for Illinois, a shapefile sourced from the Illinois State Geological Survey and developed by the United States Census Bureau. The data frame used a geographic coordinate system of WGS 1984, and the layer for Illinois state boundaries was projected in NAD 1983 Zone 16 UTM.

Towers. Tower data were imported into ArcMap as XY coordinates and saved as a point feature class. The original raw dataset included all types of obstructions in addition to communication towers, so for each copy of the point feature class, Select by Attributes was used to select all features with Structure Type defined as either tower ('TOWER'), guyed tower ('GTOWER'), or lattice structure ('LTOWER'), and a new layer was created from the selection. These selected layers were the layers used for the final version of the spatial tower data. Three different copies of the tower point feature class were saved, each symbolizing a different attribute of the tower data. Of the three copies of the tower data used, the first copy focused on tower height above ground level in meters. The second copy symbolized tower light color. The original version of this data, for the attribute 'Mark_Light,' used a 1-9 number code for each 
marking and lighting combination under Federal Aviation Administration requirements. These classes were regrouped to reflect three different classes of lighting: no lights, white lights, and red lights. Towers classified as having dual red and white lighting were grouped with red lights, because their white strobe lights operated during the day, while the red lights operated at night during bird migration. However, this class could not provide numbers for the steady-burning and flashing lights for each feature. The third class reflected whether towers were guyed or not. All features within this copy were classified as either 'TOWER' or 'GTOWER,' the latter for guyed towers, although this class could not provide an exact number of guy wire sets for each feature; all features without guy wires were classified as 'LTOWER' for lattice-supported structures.

Weather. All weather data were obtained from the application router for the NOAA online database search for hourly surface weather observations. There were 62 stations chosen in total, 46 of which had a loosely homogeneous distribution within Illinois and 16 of which were included from adjacent states to provide a complete interpolation of weather data across Illinois in ArcMap. Data was selected to the respective fall or spring migration period for each station, and was received as a text file that was then imported into Excel. In Excel, the station name, latitude and longitude coordinates were added, and data was clipped to one 5:30 UTC (23:30 CST) observation per night to account for the peak migration period. For some sites data deficient in 5:00 hourly observations, 4:00 or similar range hourly observations closest to 5:00 UTC were substituted, and those anomalous sampling times for historic tower data for the eastern United States are in Appendices E and F. Additionally, data for cloud cover and wind direction needed to be modified for analysis in Excel. All three-letter cloud cover codes needed to be replaced with numerical percent values to calculate average cloud cover (clear skies $=$ CLR, 0; few clouds $=$ FEW, 25; scattered cloud cover $=\mathrm{SCT}$, 50; broken cloud cover $=\mathrm{BKN}$, 
75 ; overcast or obscured skies $=$ OVC/OBS, 100). Obscure observations were assumed to be complete cloud cover based on the presence of a low cloud ceiling or fog in the area. Wind direction averages also had to be calculated with an 'AVERAGEIF' function to eliminate all values $>360^{\circ}$; there were faulty readings appearing as $990^{\circ}$ which would otherwise have skewed directional averages for wind. Wind speed and cloud ceiling averages were both calculated without further processing. Percentage values were calculated to determine the proportion of days with favorable winds and the proportion of days with $>50 \%$ cloud cover across Illinois for each season. Weather stations were then added into ArcMap as point feature classes. Examples of the weather station point feature classes and Kriging interpolations are in Figure 1.

Analysis of Bird Movements with NEXRAD. The methods of Buler et al. (2014) were used to process bird movements on radar and provide hotspot maps showing the seasonal density and distribution of bird migration for one fall and one spring migration season in Illinois. Bird movement data was obtained from the NOAA NEXRAD database, through radar observations for the time of peak migration starting at 5:30 UTC of the next day (23:30 CST) from study date, for the date ranges September 1 - October 31, 2016 and April 1 - May 31, 2017. The sampling time of 5:30 UTC was chosen because this time has been consistently reported as the time where peak nocturnal migration was detected by radar studies in central Illinois (Graber and Hassler 1962, Graber 1968). NEXRAD Level II data were used for all steps of analysis. Level II scans are divided into $7200.5^{\circ}$ radials, and each radial is further divided into $250 \mathrm{~m}$ segments, resulting in 331,200 initial sample volumes per radar with a radar beam height of $0.5^{\circ}$ and a range of $120 \mathrm{~km}$. Radar data were pre-scanned for all selected radar stations to eliminate scans that were clearly contaminated with precipitation. A csv file was used to record the status of each date as ' $y$ ' for yes and ' $n$ ' for 'no' for downloading, and scans were downloaded using a 
command prompt to obtain files as instructed by the csv and a Python script provided by the Aeroecology Lab at the University of Delaware. The time span for downloading was 3.5-5 hours after sunset for fall and 5-6.5 hours after sunset for spring, and the scan closest to 5:30 UTC was selected for each date downloaded.

For each radar station, a 120-km basegrid was created for ArcGIS, upon which to build clutter maps to eliminate other sources of contamination, such as bad azimuths and turbulence from wind farms and industrial sites. Clutter maps were created using summary files for each radar station, consisting of radar scans taken June 1-31, 2016, during the summer when bird movements are typically low and scans free of precipitation are clearest for detecting sources of clutter. A set of four attributes was examined to determine which sample volumes from each radar summary to discard as clutter: zpropz, propclutter, azimuth, and waterfilter. The attribute zpropz is the proportion of time within a sampling period where reflectivity is detected in a sampling volume; any sampling volumes with zpropz $\leq-2.00$ indicated low reflectivity detection and were eliminated. Similarly, propclutter is the proportion of time within the sampling period where a sampling volume detects artificially high reflectivity, from an external source such as a wind farm or industrial plant; any sample volumes with a propclutter $>0.03$ were eliminated. Azimuths were eliminated if they showed lower reflectivity than the surrounding area, indicating beam blockage close to the radar from obstructions such as buildings. Waterfilter was a measure of whether a sample volume was being taken over land or water, with $0=$ land and $1=$ water; any sample volume with a waterfilter value of 1 was eliminated. After these features were examined, a new field was created and named 'Clutter,' and all sample volumes that met any of the criteria were classified as ' 1 ' for clutter; all other features were classified as ' 0 ' for clean. 
Radar scans that were selected to download after the pre-scan were then visually scanned a second time using NOAA's Weather and Climate Toolkit software. Scans were eliminated from further use if they contained anomalous propagations, such as "spoke" patterns in the radar scan, patterns indicating insect contamination or weak bird migration, or precipitation that may have passed through the pre-scan. A virtual machine through the University of Delaware was then used to produce vertical profiles of reflectivity (VPRs) and airspeed data for each remaining scan. A 4-km altitude at a $4.5^{\circ}$ tilt was used to produce these VPRs to account for any possible migrants at higher altitudes, and to obtain a fuller view of any precipitation that escaped previous detection. These were then used to assess all radar scans a final time before producing summary files for each season and radar station. The main guiding criterion for excluding scans from further analysis was the detected target speed. All scans with a calculated target speed $<5 \mathrm{~m} / \mathrm{s}$ were excluded, based on previous evidence that insect targets and bird targets can be reliably differentiated by a $5 \mathrm{~m} / \mathrm{s}$ threshold, with most insects falling below the threshold and birds remaining above the threshold (Larkin 1991). Questionable radar scans were visually inspected in the Weather and Climate Toolkit alongside the respective VPR and airspeed data to support the decision of whether to exclude the scan. Once the final selections were made, radar data were summarized for each radar station by season and clipped to each station's respective clutter map shapefile. An R script was used to produce the final density grids from the radar summaries by season and radar. In RStudio (RStudio Team 2016), data points were excluded which had a proportion of sampled nights to total nights (ROSN/TOTALN) $<0.75$ to eliminate nights missing over $25 \%$ of sampling data, a clutter value of 1 , or a water filter value of 1 . After filtering, the $\log$ of the geometric mean reflectivity (ROSGEO + 0.001) was calculated, and the residuals of ROSGEO, along with the coefficient of variation (CVROS), were used to build each density 
grid. Density grids were divided into five different quantile classes: low density, medium density, high density/high variance, high density/medium variance, and high/density low variance. The areas of greatest bird movement over the course of one migration season were the areas with the most concentrated high density/low variance class. The resulting density grids were exported from RStudio to data folders for each radar and season, and were then imported to ArcGIS. Sources of clutter that passed through the screening process were assigned a class of Null to eliminate them from analysis in GIS. The classified densities for the seven radar stations for Fall 2016 and Spring 2017 are in Figure 2.

Two radars, KMKX and KPAH, were omitted at this stage of the analysis due to extensive overlap and minimal area that was not already covered by the other five radars. The remaining radars were clipped to within $90 \mathrm{~km}$ of the radar site to eliminate additional overlap between data. To correct for range bias of bird movement after creating the density grids, a multiple regression predicting mean reflectivity (MN) using Euclidean distance from radar and $\sin$ (azimuth) was performed in RStudio, to obtain residuals of reflectivity that were not explained by azimuth or distance from the radar station. The residuals of the corrected values were used as the final measure of bird density. All output features were then merged in ArcGIS, and then converted to seasonal rasters for residual MN.

\section{Evaluation of Tower Mortality Risk in Illinois}

A novel method was used to evaluate mortality risk using only towers within coverage of one of the five remaining radars. The tower point features for fall and spring were each clipped to the extent of the area covered by the five remaining radar stations, and a 1-km buffer was created as the zone of influence around each tower. Zonal Statistics were then used to calculate the mean MN value for each buffer zone from the residuals calculated with multiple regression models in 
RStudio; these means were output into a table, and a Join was used to merge the means with the respective attributes in the buffer zones. Formulas were then created to calculate a mortality risk index based on the factors selected for each season in the stepwise multiple regressions. The formula used for fall was:

$$
M=\left(r\left(\frac{h}{500}\right)\right)+c
$$

Where $r$ is the mean residual MN value for a tower's 1-km buffer zone, $h=$ tower height above ground level in meters, 500 meters is a constant for the average cloud ceiling altitude at which nocturnally migrating passerines are forced to fly lower and become more likely to collide with towers (Brewer and Ellis 1958, Seets and Bohlen 1977), $c$ is the numerical code for light color based on parameter estimates given in the fall ANCOVA analysis of the eastern United States (0 = white and $1=\mathrm{red})$, and $M$ is the calculated mortality risk index for a tower's $1-\mathrm{km}$ zone of influence. A similar formula was used for spring:

$$
M=\left(r\left(\frac{h}{500}\right)\right)+w
$$

Where $w$ is the average wind speed calculated for a tower site as selected by the stepwise multiple regression analysis for the eastern United States in spring (light color for the eastern United States in spring could not be analyzed with an ANCOVA due to low sample size of towers with white lights). Both formulas were used to calculate new fields for the buffer zone layers for each season, and both outputs were symbolized on a green-to-red color gradient divided into ten classes, labeled on an ordinal scale of 1-10 from lowest to highest mortality risk. After output point feature classes were finalized in GIS for each season, a simple regression was 
performed to measure the accuracy of calculated $M$ values for the log-transformed kill means in fall (the spring sample size was too small to use in analyses). 


\section{CHAPTER III: RESULTS}

\section{Principal Component Analysis}

Four separate Principal Component Analyses were performed on the tower compilations, addressing tower and weather factors for the eastern United States and Illinois. The tower PCA for the eastern United States compilation resulted in two eigenvalues $>1.0$, and two significant factors for tower parameters (Tables 1 and 2). The first factor was composed of a negative loading for tower height and a positive loading for site elevation. Large negative PC1 scores for a tower thus indicate tall towers in low-elevation areas, and conversely, large negative PC1 scores indicated shorter towers in high-elevation areas. The second factor was composed of a positive loading for number of steady lights and a negative loading for number of flashing lights, together encompassing tower lighting systems; large positive PC2 scores indicate steady lights whereas large negative scores indicate flashing lights. A similar pattern was seen in the eigenvalues and significant factors for the Illinois tower PCA, but the first and second factors appear in reverse order. The results of this PCA are in Tables 5 and 6.

The weather PCA for the eastern United States resulted in two eigenvalues $>1.0$, and the Illinois weather PCA resulted in two eigenvalues >1.0 (Tables 3 and 7). In both the eastern United States and Illinois PCAs, the first PC had large positive loadings for both cloud cover and percentage of days with $>50 \%$ cloud cover, and large negative loadings for cloud ceiling, all parameters typical of inclement weather that can increase tower kill risk for migrating birds. The weather parameters concerning wind (wind direction, wind speed, and percentage of days per season with favorable winds) were scattered among the second, third and fourth weather factors, respectively, in both PCAs. In the eastern United States weather PCA, wind speed was the third factor and percentage of days with favorable winds was the fourth factor, but the ordering of 
these factors was reversed in Illinois (Tables 4 and 8). All PC scores for the eastern United States and Illinois towers are in Tables S5-S8.

\section{Stepwise Multiple Regression}

In the stepwise multiple regression analysis, the first tower factor was selected for the eastern United States, displaying a negative trend (Tables 9 and 10). Conversely, the first tower factor and the third weather factor were selected for the eastern United States towers in spring, with both showing negative trends (Tables 11 and 12). Light color was selected for Illinois in the fall, for which red lights showed a positive trend and white lights were zero (Tables 13 and 14). In the spring, the first and third tower factors were selected for Illinois, and displayed a negative trend (Tables 15 and 16).

The eastern United States dataset was chosen for plotting the relationships between the selected PC factors. In the fall, log mean kills showed a negative relationship with the first tower factor, and towers with white lighting or no lighting were among the lowest calculated log mean kills (Figure 3). A three-dimensional scatter plot of spring stepwise factors is in Figure 4.

\footnotetext{
ANCOVA

Three out of the four datasets could not be analyzed by ANCOVA. Both seasons in Illinois had small sample sizes. Fall data for Illinois could not be analyzed by ANCOVA due to the absence of numerical variables selected by the stepwise multiple regression, and spring data could not be interpreted because only one light color, red, was present. Spring data for the eastern United States could not be interpreted because there were too few observations; only one tower in the eastern United States spring sample had white lighting.
} 
Preliminary analysis of the fall data for the eastern United States resulted in failure to reject the null hypothesis assuming equal slopes for the two light colors. Although no covariation was found between light color and the first tower factor (model Pr > F 0.052; Tower Factor $1 *$ Light Color interaction $\operatorname{Pr}>\mathrm{F} 0.534, \mathrm{DF}=2$ ), light color still significantly affected the logtransformed means independently (Light Color Pr $>$ F 0.011, DF = 1; Tower Factor 1 Pr $>$ F 0.0856, DF $=1$ ), with red lights contributing to higher kill means than white lights (LS mean red $=2.3491, \mathrm{LS}$ mean white $=1.2523)$. Tower Factor 1 produced a slope estimate of -0.1551 , which is in agreement with the negative loading for tower height in Tower Factor 1 in the PCA.

\section{Analysis of Bird Movements with NEXRAD}

Multiple regression analyses of azimuth and distance effects on the log-transformed MN values from radar in RStudio produced strongly correlated models for all radars in both seasons, and most bias originated from distance from radar (Tables S9-S18). High degrees of freedom throughout the regression analyses originate from the large number of sample volumes in each radar summary. The corrected density grids are in Figure 5. Residuals from the regression models indicate high densities of birds near the outer $90 \mathrm{~km}$ of the extents to the west and east of the five radar stations in both Fall 2016 and Spring 2017, and areas of the lowest density were to the north of the KDVN and KILX stations in spring.

\section{Evaluation of Tower Mortality Risk in Illinois}

Outputs displaying the mortality index for towers within coverage of each of the five radars by season are in Figures 6 and 7. A detail of the output shows the classifications of towers in central Illinois in fall and spring, spanning from Springfield to Champaign, which have been the subjects of previous tower kill studies (Figure 8). Classifications are according to the towers' current 
characteristics and not characteristics of previous towers at the same sites. Statewide maps of Illinois showing comparison of radar-covered towers to data-deficient towers are in Figure 9. A simple regression evaluating the accuracy of the fall model in regard to previously documented tower kills at Illinois tower sites is in Figure 10. 


\section{CHAPTER IV: DISCUSSION}

\section{Compilations of Historic Tower Kill Reports}

The compilations of tower kill reports to be used in the evaluation of the avian tower kill risk for Illinois presented the most unique challenges and required the most time for all parts of the project. Methods of collecting specimens and recording kill conditions differed between reports, and in many cases paper authors had to be contacted directly to obtain data for some of the parameters to complete statistics for tower characteristics, kill maxima, means and standard deviations, and sometimes history of the tower site itself for proper context of determining conditions contributing to a major kill. Many tower kill reports that had previously been considered for inclusion in the compilations had to be omitted due to inaccessibility of some data parameters, often due to the age of the study and the authors being deceased. FCC records were used to complete tower characteristics, but because tower specifications for each entry were based on the most recent tower building date for the site, some entries in the historic compilations had to be corrected to match the conditions given in the corresponding report. Weather data were obtained directly from NOAA based on kill dates provided in papers or by authors, and there were both chronological and geographical gaps in the NOAA archives that resulted in null entries for the weather data of some tower kill reports. Different iterations of the same tower site in the compilations were also required due to differences in height, lighting style, or both. These discrepancies in the compiled tower kill data most likely influenced the outcome of the statistical analyses, especially the stepwise multiple regression and ANCOVA tests. Small sample sizes for all compilations, especially the Illinois compilations, resulted in higher error and less predictive power in evaluating the most influential factors for tower kill risk. 


\section{Principal Component Analysis}

The observed differences in the order and composition of factors resulting from the Principal Component Analyses of the eastern United States and Illinois can likely be attributed to sample size and variability in elevation. The data compilation for the eastern United States is 2-3 times larger than the compilation of reports exclusive to Illinois, and therefore any modifications or corrections made to these datasets to ensure historical accuracy are more likely to affect the smaller Illinois dataset. The smaller sample size for Illinois also means an overall increase in standard error and less predictive power. Before the final PCA, two corrections were made to the lighting style for two tower entries, one in the eastern United States dataset, where the lighting color and numbers of steady and flashing lights were changed, and one in the Illinois dataset, where one tower entry was split into two to account for different iterations of the tower site with different light colors and numbers. The resulting PC factors were in different order for the two datasets, with site elevation and tower height composing the first factor and the numbers of steady-burning and flashing lights being the second factor in the eastern United States analysis, while the order of these factors was reversed in the Illinois analysis. Site elevation may also play a major role in the ordering of these factors, since the eastern United States dataset covers a wider geographic area and includes regions with a higher variability in elevation, while Illinois is a more limited region with much smaller elevation differential.

The composition of the factors resulting from the Principal Component Analyses partially supported the hypothesis by Gehring et al. (2009) that taller towers with more guy wires and more red, steady-burning lights present a higher mortality risk for birds. In both the eastern United States and Illinois datasets, the first two factors were composed of parameters pertaining to overall tower height and the number of lights present on a tower. The number of guy wire sets 
constituted the third factor in both datasets, indicating that the number of guy wire sets did not contribute to as much variation as expected under this hypothesis. The Principal Component Analysis was unable to address class variables, such as lighting color, and it remains unknown which factor would incorporate light color in its composition.

The composition of the PC factors supported the hypothesis by Larkin and Frase (1988) that extensive cloud cover, a low cloud ceiling altitude, and poor visibility weather conditions present higher mortality risks for birds. In both datasets, the first PC factor was composed of parameters that are characteristic of adverse weather conditions (extensive cloud cover, low cloud ceiling, and high proportion of days with overcast skies). The wind parameters (average wind direction, wind speed, and percentage of days with favorable winds) were scattered among the remaining three factors, with wind direction composing the second factor in both datasets. However, the circular measurement of wind direction in degrees likely affected the order of this factor since the sample set for wind direction used to calculate averages was as variable as the dependent variables of mean kill numbers.

\section{Stepwise Multiple Regression}

Due to a small sample size, the Illinois stepwise multiple regressions were omitted from graphing. In both datasets, the PC factors selected by the stepwise multiple regressions partially follow the hypotheses given in previous reports. The first tower factor (tower height and site elevation for the eastern United States and numbers of steady and flashing lights for Illinois) prevailed in both datasets for both seasons, but neither dataset had its tower factor for number of guy wire sets selected. The Illinois dataset was more influenced by weather factors than the eastern United States, likely because of differing weather patterns between a more restricted and a more general geographic region. Weather also more strongly influenced log kill numbers in the 
spring for the eastern United States, which can be explained by the unstable weather conditions that prevail during the spring across the region (Bagg et al. 1950).

Tower height and elevation contributed to the trend for the eastern United States log mean kills in the fall, partially supporting the hypothesis by Gehring et al. (2009) that taller towers with red lighting present the highest risk for major tower kill events. The trend had a loose negative correlation, reflected in the first tower factor in which elevation was the positive loading and tower height was the negative loading, and log mean kills increased as PC scores for the first tower factor decreased. The tower with no lighting was among the lowest log mean kills, and the four towers with white lighting had lower log mean kills than most of the towers with red lighting. The Illinois dataset only partially supported the Gehring et al. (2009) hypothesis, because light color was selected, but not the first tower factor composed of lighting parameters, the second tower factor composed of tower height parameters or the third factor composed of number of guy wire sets.

In both datasets, the hypothesis by Larkin and Frase (1988) that extensive cloud cover, low cloud ceiling altitude and poor visibility weather conditions was only partially supported. In the eastern United States dataset, the third weather factor for wind speed was selected for spring, and in the Illinois dataset, the first and third weather factors, for cloud cover, ceiling and percentage of days with $>50 \%$ cloud cover, and percentage of days with favorable wind, respectively, were selected. The prominence of selected wind factors in spring for both datasets is indicative of the importance of favorable winds for spring migration. Birds have a greater urgency to return to their summer range in the spring to have enough time to breed and thus have low plasticity in the timing of spring migration, whereas fall migration to the wintering grounds occurs at a more leisurely pace (Stanley et al. 2012, Nilsson et al. 2013). The strength of 
favorable winds has been directly correlated with the numbers of birds that arrive on North American shores during the northward spring migration (Bagg et al. 1950, Gauthreaux 1971).

\begin{abstract}
ANCOVA
The model for the eastern United States fall sample was significant, and light color still had a noticeable effect on the log-transformed tower kill means without being a covariate to Tower Factor 1 (tower height and elevation). Towers with red lights had higher log means than towers with white lights. This finding is in support of Gehring et al.'s (2009) hypothesis regarding light color, but only partially because the effect of the number of steady-burning and flashing lights remains unknown and because light color produced significant effects independently of tower height. Correlation was weak, likely due to a small sample size, and a smaller subset of towers with white lights (four).
\end{abstract}

\title{
Analysis of Bird Movements with NEXRAD
}

The hypothesis that broad-front migration would yield no significant hotspots of bird density in Illinois except around the Lake Michigan shoreline was partially supported in this study. Lake Michigan showed a greater concentration of higher residuals in the spring than in the fall. Most high residuals were around the edges of the extent covered by the five radars used. This pattern can be explained by sampling time ( 5:30 UTC), as most birds have already reached peak altitude, and at this sampling time will most likely be detected further away from the radar station where the radar beam is higher in the atmosphere. Birds will have also already dispersed from their stopover areas on the ground, and exhibit no discernable pattern after having reached migration altitude over flat terrain. 
Previous attempts have been made to characterize bird migration hotspots using NEXRAD scans on a regional scale. One such attempt was by Schools et al. (2012), who summarized radar scans free of precipitation at a peak migration time closest to 23:30 local time (5:30 UTC), and used the reflectivity of scan summaries to determine hotspots using the Getis Ord Gi* Hotspot Analysis in ArcGIS. However, their study contained several limitations that can confound interpretation of the detected hotspots. First, the methods used did not account for range bias, where the altitude of the radar beam increases due to the curvature of the Earth, and reflectivity decreases with increased distance from the radar, consequently passing over migrating birds at farther distances. Schools et al. (2012) measured reflectivity in 1-km concentric distances between $20 \mathrm{~km}$ and $120 \mathrm{~km}$ away from the radar. However, what was not attempted was a regression model predicting bird density with distance from radar as an explanatory variable, which can account for range bias by examining the data as one entity rather than breaking data into several smaller segments. A threshold reflectivity value was calculated for each distance so that no more than $5 \%$ of the sample at each distance was above the threshold. However, this approach still cannot fully ameliorate observed "butterfly" patterns that occur when birds travel head-on or tail-on in relation to the radar, rather than parallel or side-on (Diehl and Larkin 2005).

By contrast, more recent methods developed by Buler et al. (2014) account for range bias, sources of clutter beyond precipitation, and anomalous propagation. Radar scans were visually examined three times before and during processing to eliminate precipitation, and both VPRs and target speeds were used to separate birds from other radar targets. Higher beam angles were included up to $4.5 \mathrm{~km}$ above the Earth to account for birds migrating at different altitudes. Four different parameters were used to eliminate other sources of clutter in the summarized radar 
shapefiles, such as turbulence from wind farms or factories, sampling over water, or poor

azimuthal readings. Bird movements were grouped into five classes based on the density of birds and the level of variation within the detected density. Additional range bias post-classification was eliminated with the conversion of azimuth to radians and applying a sine function to the geometric mean regression on order statistics (ROSGEO) in the RStudio multiple regression.

\section{Evaluation of Tower Mortality Risk in Illinois}

The two formulas used for evaluating avian mortality risk for all towers within radar coverage in Illinois provide a reliable method for determining which towers present the greatest risk to birds based on both bird movements and contributing factors from weather and towers on the ground. An examination of tower sites that have been studied in previous tower kill reports supports the hypothesis that taller towers with red lights are more dangerous to birds. In an expanse stretching from Springfield to Champaign, the tall, red-lighted WICS TV tower (index of 4) and WCIA tower (index of 6) had higher indices than WRSP-TV (index of 1), WAND (index of 1), WBUI (index of 1) and WILL-TV (index of 1), which had white lights. While a test of the fall model by simple regression of eight tower sights with historic kill statistics against the calculated values of $M$ gave a strong positive correlation, the small sample size presents a caveat of low representation of Illinois towers. A larger sample size of towers, likely encompassing a larger area with greater implementation of the model, is still needed for a more accurate assessment of whether the fall model is robust. Evaluation of mortality risk in the spring was strongly influenced by wind speed, with a much higher number of towers that would have otherwise had a lower ranking in the fall, being classified into the higher rankings in orange and red in the spring. This can be explained by more birds timing their migration according to favorable conditions in order to maximize travel efficiency and reach their breeding grounds for the spring (Nilsson et al. 
2013). As consequence, with more birds travelling under favorable conditions at a low enough altitude, chances are higher of more birds colliding with towers or the towers' guy wires, with tower height or light color not holding as high importance as in the fall.

Different sample sizes of towers must be accounted for when interpreting the predicted mortality risk maps. In the original tower point feature class, there were three different classes of lighting: no lights, white lights, and red lights. While light color was significant for fall in the ANCOVA for the eastern United States dataset of historic kill reports, there were not enough observations of unlit towers to provide a parameter estimate for this lighting class. This left two options for approaching the classification of unlit towers in GIS: either use the average of the numerical values representing the classes of towers with white lights and towers with red lights, or omit unlit towers from GIS analysis altogether. The latter option was chosen to avoid inaccurate assumptions regarding the absence of lighting on bird mortality at towers. Although unlit towers have consistently resulted in lower bird mortality (Cochran and Graber 1958, Gauthreaux and Belser 2006), the stepwise analysis in this study could not provide support for this finding. The omission of unlit towers for fall, but not for spring where tower lighting was not selected from the stepwise multiple regression, resulted in two different sample sizes for the fall and spring. The original sample size, which was retained for the spring, was 3,718 towers. After unlit towers were omitted for the fall, the fall sample size was 2,261 towers. After being clipped to the extent of the area of Illinois with radar coverage, the numbers of towers for spring and fall were 2,280 (61\% of total towers) and 1,323 (36\% of total towers), respectively. While this is still a large sample size, the effect of unlit towers on bird mortality relative to Illinois specifically remains unknown, and the different sample sizes and explanatory variables cause disparity 
between the understanding of the major contributing factors to tower kills in spring versus the fall.

Another discrepancy between historical reports and current GIS methods is that for most of the Illinois towers, the numbers of flashing and steady-burning lights are not known. Only the 15 towers included in the compilations of historic tower kills reports had documented numbers of lights, or could readily have these numbers augmented by FCC or FAA circulars; the tower data obtained directly from the FCC did not have fields detailing numbers of each light type for tower entries. The Principal Component factors constituting numbers of flashing and steady-burning lights were also not selected by the stepwise multiple regression. Thus, the impact of the number of lights on a tower on the mortality risk it presents remains unknown.

Only eight of the thirteen tower sites still in use since being studied in Illinois could be used for the simple regression measuring the accuracy of the formulas in predicting $M$ for the fall season. One tower, WJJY in Bluffs, no longer exists, three more towers were outside of radar coverage and therefore did not have $M$ values, and one tower, WILL-TV in Monticello, had different characteristics than it had at the time it was studied, so the calculated $M$ value would not have reflected its current risk. However, of the eight towers that were used for the regression, there was an $\mathrm{R}^{2}$ of 0.76 , indicating a strong correlation between the $M$ values calculated using the formula for fall and mortality trends at the towers given their set of characteristics. Only two towers from the total set had $M$ values matching the towers' current characteristics for spring, so a regression could not be performed to measure the accuracy of the spring formula. The spring sample is likely not as accurate due to the large weight of average wind speed in the formula. Methods to improve accuracy of the formula using the stepwise selected factors could include transforming average wind speed values or giving average wind speed a different function in the 
formula. The fall formula was also calculated with larger tower buffer distances of 2, 3, 4 and 5 $\mathrm{km}$, but the 1-km buffers were still the most effective due to smaller sample sizes of available towers with historic data and slightly weaker correlations in the four larger buffer distances.

\section{Conclusions}

This project represents the first attempt at spatially quantifying the risk of avian mortality at communication towers on a statewide scale for any state. It also presents a novel method that can be replicated with other states, and serviced as an environmental impact assessment to gauge what modifications need to be made to new planned towers or currently existing towers which already present a high risk to birds. Hypotheses for tower characteristics and weather conditions contributing to the most favorable conditions for major mortality events were only partially supported in analyses of past tower studies. However, enough previously documented trends, including tower height and light color, were relevant in the GIS results to refine this method to improve bird safety standards in the communications industry, and help conserve populations of many already-threatened Neotropical migrant passerine bird species.

\section{Future Directions}

Future studies should involve using Geographically Weighted Regression to produce a continuous prediction of bird density across the state of Illinois, and improve replicability of the methods to be used in environmental impact assessments in the communications industry across other states. In areas with significant land elevation changes, elevation should be added to the formulas produced, to account for possible altitudinal changes in bird migration. Further attempts to spatially quantify kill risk should also involve developing methods to account for the numbers of flashing and steady-burning lights on towers, in addition to tower light color. Additionally, a 
matrix should be created to measure differences in avian mortality risk index among towers during spring and fall migration seasons. Larger sample sizes of historic tower kill reports from other regions should be included to test the accuracy of future models with regressions across both fall and spring seasons. 


\section{REFERENCES}

Anonymous. (1961.) Large bird kills at TV towers. The Bluebird 28:9.

Askins, R. A., and M. J. Philbrick (1987). Effects of changes in regional forest abundance on the decline and recovery of a forest bird community. The Wilson Bulletin 99:7-21.

Avery, Michael, Paul F. Springer, and J. Frank Cassel. (1976). The effects of a tall tower on nocturnal bird migration: a portable ceilometer study. The Auk 93:281-291.

Avery, M. L., P. F. Springer, and J. F. Cassel. (1977). Weather influences on nocturnal bird mortality at a North Dakota tower. The Wilson Bulletin 89:291-299.

Avery, M. L., Springer, P. F., \& Cassel, F. (1978). The composition and seasonal variation of bird losses at a tall tower in southeastern North Dakota. American Birds 32:1114-1121.

Avery, M. L., P. F. Springer, and N. S. Dailey. (1980). Avian mortality at man-made structures: An annotated bibliography (revised). No. 80/54. US Fish and Wildlife Service.

Bagg, Aaron M., W. W. H. Gunn, D. S. Miller, J. T. Nichols, Winnifred Smith, and F. P. Wolfarth. (1950). Barometric pressure-patterns and spring bird migration. The Wilson Bulletin 62:5-19.

Baird, J. (1970). Mortality of fall migrants at the Boylston television tower in 1970. The Chickadee 40:17-21.

Baird, J. (1971). Mortality of fall migrants at the Boylston television tower in September of 1971. The Chickadee 41:20-24.

Ball, L. G., K. Zyskowski, and G. Escalona-Segura. (1995). Recent bird mortality at a Topeka television tower. Kansas Ornithological Society Bulletin 46:33-36. 
Banks, R. C. (1979). Human related mortality of birds in the United States. United States Department of the Interior Fish and Wildlife Service. Special Scientific ReportWildlife no. 15.

Barkley, R., C. Elk and J. Palmquist. (1977). Recent TV tower kills at Goodland, Kansas. Kansas Ornithological Society Bulletin 28:10-12.

Bellrose, F. C. (1971). The distribution of nocturnal migrants in the air space. The Auk 88:397424.

Bennett, E.M., G. D. Peterson, and L. J. Gordon. (2009). Understanding relationships between multiple ecosystem services. Ecology Letters 12:1394-1404.

Bierly, M. L. (1971). Fall television tower casualties in Nashville. The Migrant 44:5-6.

Bivens, S., and J. Nehring. (2015). An overview of a 51 year study of bird casualties at Nashville’s WSMV television tower 1960-2010. The Migrant 86:113-132.

Blake, J. G., and B. A. Loiselle (1992). Fruit in the diets of Neotropical migrants in Costa Rica. Biotropica 24:200-210.

Bohlen, H. D. (1980). Age and sex composition of a TV-tower kill near Springfield. Illinois Birds and Birding 1:61-62.

Boso, B. (1965). Bird casualties at a southeastern Kansas TV tower. Transactions of the Kansas Academy of Science (1903-) 68:131-136.

Brewer, R., and J. A. Ellis (1958). An analysis of migrating birds killed at a television tower in east-central Illinois, September 1955-May 1957. The Auk 75:400-407. 
Buler, J. J., and D. Dawson (2014). Radar analysis of fall bird migration stopover sites in the northeastern U.S. The Condor 116:357-370.

Buss, I. O. (1946). Bird detection by radar. The Auk 63:315-318.

Carver, E. (2013). Birding in the United States: A Demographic and Economic Analysis. United States Fish and Wildlife Service, Report 2011-1.

Cody, M. L. (1981). Habitat selection in birds: the roles of vegetation structure, competitors, and productivity. Bio-Science 31:107-113.

Cochran, W. W., and R. R. Graber. (1958). Attraction of nocturnal migrants by lights on a television tower. The Wilson Bulletin 70:378-380.

Crawford, R. L. (1978). Autumn bird casualties at a northwest Florida TV tower: 1973-1975. The Wilson Bulletin 90:335-345.

Crawford, R. L., and R. T. Engstrom. (2001). Characteristics of avian mortality at a north Florida television tower: A 29-year study. Journal of Field Ornithology 72:380-388.

Diehl, R. H., and R. P. Larkin. (2005). Introduction to the WSR-88D (NEXRAD) for ornithological research. In: Ralph, C. John; Rich, Terrell D., editors 2005. Bird Conservation Implementation and Integration in the Americas: Proceedings of the Third International Partners in Flight Conference. 2002 March 20-24; Asilomar, California, Volume 2 Gen. Tech. Rep. PSW-GTR-191. Albany, CA: US Dept. of Agriculture, Forest Service, Pacific Southwest Research Station 191:876-888.

Elder, W. H., and J. Hansen. (1967). Bird mortality at KOMU-TV tower, Columbia, Missouri, fall 1965 and 1966. The Bluebird 34:3-6. 
Ellis, C. D. (1997). Back to the tower: Tower-killed birds at a Putnam County, West Virginia, television transmission tower. The Redstart 64:111-113.

Environmental Science Research Institute. (2011). ArcGIS Desktop: Release 10. Redlands, CA: Environmental Systems Research Institute.

Ewert, D.N., G.J. Soulliere, R.D. Macleod, M.C. Shieldcastle, P.G. Rodewald, E. Fujimura, J. Shieldcastle, and R.J. Gates. (2005). Migratory bird stopover site attributes in the western Lake Erie basin. Final report to The George Gund Foundation.

Feehan, J. (1963). Birds killed at the Ostrander TV tower. The Flicker 35:111-112.

Ganier, A. F. (1962). Bird casualties at a Nashville TV tower. The Migrant 33:58-60.

Gauthreaux, S. A. Jr. (1971). A radar and direct visual study of passerine spring migration in southern Louisiana. The Auk 88:343-365.

Gauthreaux, S. A. Jr., and C. Belser (2003). Radar ornithology and biological conservation. The Auk 120:266-277.

Gauthreaux, S. A. Jr., and C. Belser. (2006). Effects of artificial night lighting on migrating birds. Ecological consequences of artificial night lighting, In C. Rich, and T. Longcore, eds., pp. 67-93.

Gehring, J., P. Kerlinger, and A. M. Manwell II (2009). Communication towers, lights, and birds: Successful methods of reducing the frequency of avian collisions. Ecological Applications 19:505-514.

George, W. (1963). Columbia tower fatalities. The Bluebird 30:5. 
Goodpasture, K. A. (1974a). Fall 1972 television tower casualties in Nashville. The Migrant 45:29-31.

Goodpasture, K. A. (1974b). Fall 1973 television tower casualties in Nashville. The Migrant 45:57-59.

Goodpasture, K. A. (1975). Nashville television tower casualties, 1974. The Migrant 46:49-51.

Goodpasture, K. A. (1976). Nashville television tower casualties, 1975. The Migrant 47:8-10.

Goodpasture, K. A. (1984). Television tower casualties, Nashville, Tennessee 1976-1983. The Migrant 55:53-57.

Goodpasture, K. A. (1986). Nashville, Tennessee television tower casualties, 1984. The Migrant 57:70-72.

Graber, R., and S. S. Hassler. (1962). The effectiveness of aircraft-type (APS) radar in detecting birds. The Wilson Bulletin 74:367-380.

Graber, R. (1968). Nocturnal migration in Illinois - Different points of view. The Wilson Bulletin 80:36-71.

Herron, J. (1997). Television transmission tower kills in Lewis County, West Virginia. The Redstart 64:114-117.

Hufford, D. (2001). Towering injustice. Birder's World June 2001: 40-43.

Jedlicka, J. A., R. Greenburg, and D. K. Letourneau. (2011). Avian conservation practices strengthen ecosystem services in California vineyards. PLoS ONE 6:e27347. doi:10.1371/journal.pone.0027347. 
Kale, H. W. II. (1971). Florida region. American Birds 25:723-735.

Kellerman, J. L., M. D. Johnson, A. M. Sterchl, and S. C. Hackett (2008). Ecological and economic services provided by birds on Jamaican Blue Mountain coffee farms. Conservation Biology 22:1177-1185.

Kerlinger, P. and F. R. Moore. (1989). Atmospheric structure and avian migration. Current Ornithology 6:109-142.

Kleen, V. M. (1978). Field notes: Fall migration. Illinois Audubon Bulletin 183:40.

Kleen, V. M. (1979). Field notes: Fall migration. Illinois Audubon Bulletin 184:39.

Kleen, V. M., and L. Bush. (1973). Middlewestern prairie region. American Birds 27:777-781.

Kruse, K. (1996). A study of the effects of transmission towers on migrating birds. University of Wisconsin. Master of Science thesis.

Lack, D., and G. C. Varley. (1945). Detection of birds by radar. Nature 156:446.

Larkin, R. P. (1991). Flight speeds observed with radar, a correction: Slow "birds" are insects. Behavioral Ecology and Sociobiology 29:221-224.

Larkin, R. P., and B. A. Frase (1988). Circular paths of birds flying near a broadcasting tower in cloud. Journal of Comparative Psychology 102:90-93.

Laskey, A. R. (1960). Bird migration casualties and weather conditions autumns 1958-19591960. The Migrant 31:61-65.

Laskey, A. R. (1962). Migration data from television tower casualties at Nashville. The Migrant $33: 7-8$. 
Laskey, A. R. (1963a). Casualties at WSIX TV tower in autumn, 1962. The Migrant 34:15.

Laskey, A. R. (1963b). Mortality of night migrants at Nashville TV towers, 1963. The Migrant 34:65-66.

Laskey, A. R. (1964). Data from the Nashville TV tower casualties autumn 1964. The Migrant 35:95-96.

Laskey, A. R. (1967). Spring mortality of Black-poll Warblers at a Nashville TV tower. The Migrant: 38:43.

Laskey, A. R. (1968). Television tower casualties at Nashville, autumn 1967. The Migrant 39:25-26.

Laskey, A. R. (1969a). TV tower casualties at Nashville in autumn 1968. The Migrant 40:25-26.

Laskey, A. R. (1969b). Autumn 1969 TV tower casualties at Nashville. The Migrant 40:79-80.

Laskey, A. R. (1971). TV tower casualties at Nashville: spring and autumn, 1970. The Migrant 42:15-16.

Longcore, T., C. Rich, P. Mineau, B. MacDonald, D. G. Bert, L. M. Sullivan, E. Mutrie, S. A. Gauthreaux, Jr., M. L. Avery, R. L. Crawford, A. M. Manville II, E. R. Travis and D. Drake. (2013). Avian mortality at communication towers in the United States and Canada: Which species, how many, and where? Biological Conservation 158:410-419.

Loss, S. R., T. Will, and P. P. Marra (2015). Direct mortality of birds from anthropogenic causes. Annual Review of Ecology, Evolution, and Systematics 46:99-120. 
Lundstrom, L. A., D. J. Horn, and A. P. Capparella (2013). The effects of tower structure and weather conditions on avian mortality at three television towers in central Illinois. Transactions of the Illinois State Academy of Science 109:9-12.

Mäntalyä, E., T. Klemola, and T. Laaksonen. (2011). Birds help plants: a meta-analysis of topdown trophic cascades caused by avian predators. Oecologia 165:143-151.

Manuwal, D. D. (1963). TV transmitter kills in South Bend, Indiana, fall 1962. Indiana Audubon Quarterly 41:49-53.

Moore, F. R. (1987). Sunset and the orientation behavior of migratory birds. Biological Reviews 62: 65-86.

Moore, F. R., P. Kerlinger, and T. R. Simons. (1990). Stopover on a Gulf Coast barrier island by spring trans-gulf migrants. The Wilson Bulletin 102:487-500.

Morris, S. R., A. R. Clark, L. H. Bhatti, and J. L. Glasgow. (2003). Television tower mortality of migrant birds in western New York and Youngstown, Ohio. Northeastern Naturalist 10:67-76.

Mosman, D. (1975). Bird casualties at Alleman, IA TV tower. Iowa Bird Life 45:88-90.

Mumford, R. E. (1960). Fall migration: Middlewestern prairie region. Audubon Field Notes $14: 38-41$.

Nehring, J., and S. Bivens. (1999). A study of bird mortality at Nashville's WSMV television tower. The Migrant 70:1-8. 
Neisslie, J. G., D. J. Horn, and A. P. Capparella. (unpublished manuscript). Can avian mortality at television towers in central Illinois serve as an indicator of population trends of nocturnal migrants?

Nicholson, C. P. (1984). September 1984 tower kill in Knox County, Tennessee. The Migrant $55: 86$.

Nicholson, C. P., R. D. Tankersley Jr, J. K. Fiedler and N. S. Nicholas. (2005). Assessment and prediction of bird and bat mortality at wind energy facilities in the southeastern United States. Final Report. Tennessee Valley Authority, Knoxville, Tennessee.

Nilsson, C., R. H. G. Klaassen, and T. Alerstam. (2013). Differences in speed and duration of bird migration between spring and autumn. The American Naturalist 181:837-845.

Parmalee, P. W., and B. G. Parmalee. (1959). Mortality of birds at a television tower in central Illinois. Illinois Audubon Bulletin 111:1-4.

Parmalee, P. W., and M. D. Thompson. (1963). A second kill of birds at a television tower in central Illinois. Illinois Audubon Bulletin 128:13-15.

Peisley, R. K., M. E. Saunders, and G. W. Luck. (2016). Cost-benefit trade-offs of bird activity in apple orchards. PeerJ 4:e2179.

Petersen Jr, P. C. (1959). TV tower mortality in western Illinois. Bulletin of the Illinois Audubon Society 11:14-15.

Robbins, C.S., J.R .Sauer, R.S. Greenberg,. and S. Droege. (1989). Population declines in North American birds that migrate to the Neotropics. Proceedings of the National Academy of Science USA 86:7658-7662. 
Robbins, M. B., B. R. Barber, and E. A. Young. (2000). Major bird mortality at a Topeka television tower. Kansas Ornithological Society Bulletin 51:29-30.

Rosche, R. C. (1971). The fall migration: Western New York and northwestern Pennsylvania. American Birds 25:54-57.

RStudio Team (2016). RStudio: Integrated Development for R. RStudio, Inc., Boston, MA URL http://www.rstudio.com/.

Sample, B. E., R. J. Cooper, and R. C. Whitmore. (1993). Dietary shifts among songbirds from a diflubenzuron-treated forest. The Condor 95:616-624.

SAS Institute Inc (2013). SAS/ACCESS® 9.4 Interface to ADABAS: Reference. Cary, NC: SAS Institute Inc.

Sauer, J. R., W. A. Link, J. E. Fallon, K. L. Pardieck, and D. J. Ziolkowski, Jr. (2013). The North American Breeding Bird Survey 1966-2011: Summary analysis and species accounts. North American Fauna 79: 1-32.

Sawyer, P. J. (1961). Bird mortality at the WENH-TV tower in Deefield, New Hampshire. New Hampshire Audubon Quarterly 14:46-49.

Scheffers, B. R., L. N. Joppa, S. L. Pimm, and W. F. Laurance. (2012). What we know and don't know about Earth's missing biodiversity. Trends in ecology \& evolution 27:501-510.

Schools, E. H., H. D. Enander, J. L. Gehring, B. J. Klatt, and C. A. Forgacs. (2012). Utilizing NEXRAD weather data and a hotspot analysis to determine bird migration concentration areas. Michigan Natural Features Inventory, Report Number 2014-21, Michigan State University, Lansing, MI. 
Seets, J. W., and H. D. Bohlen (1977). Comparative mortality of birds at television towers in central Illinois. The Wilson Bulletin 89:422-433.

Shire, G. G., K. Brown, and G. Winegrad (2000). Communication towers: A deadly hazard to birds: A report. American Bird Conservancy.

Sillett, T.S., and R.T. Holmes. (2002). Variation in survivorship of a migratory songbird throughout its annual cycle. Journal of Animal Ecology 71:296-308.

Stanley, C. Q., M. MacPherson, K. C. Fraser, E. A. McKinnon, and B. J. Stutchbury. (2012). Repeat tracking of individual songbirds reveals consistent migration timing but flexibility in route. PloS One 7:e40688.

Stoddard, H. L. (1962). Bird casualties at a Leon County, Florida TV Tower. Tall Timbers Research Station.

Strnad, F. V. (1962). Birds killed at the KROC-TV tower, Ostrander, Minnesota. The Flicker 34:7-9.

Strnad, F. V. (1975). More bird kills at KROC-TV tower, Ostrander, Minnesota. The Loon $47: 16-21$.

Tanner, J. T., R. J. Dunbar, A. F. Ganier, L. R. Herndon, A. R. Laskey and A. H. West. (1954). Bird mortality during night migration, October 1954. The Migrant 25:57-68.

Taylor, W. K., and B. H. Anderson. (1973). Nocturnal migrants killed at a central Florida TV tower; autumns 1969-1971. The Wilson Bulletin 85:42-51.

Taylor, W. K., and B. H. Anderson. (1974). Nocturnal migrants killed at a central Florida TV tower; autumn 1972. Florida Field Naturalist 2:40-43. 
Thompson, M. D. (1958). Bird mortality at TV tower. Illinois Audubon Bulletin 108:2.

Travis, E. (2009). Impacts of communication towers on avian migrants. University of WisconsinMadison. Master of Science Thesis (Forest and Wildlife Ecology).

Tremblay, A., P. Mineau and R. K. Stewart. (2001). Effects of bird predation on some pest insect populations in corn. Agriculture, Ecosystems and Environment 83:143-152.

Turner, L., and M. Davis. (1980). Birds killed at television towers in Knox County. The Migrant $51: 27-29$.

United States Department of the Interior (2018). Guidance on the recent M-Opinion affecting the Migratory Bird Treaty Act. FWS/AMB/067711.

Van Bael, S. A., P. Bichier, and R. Greenburg. (2007). Bird predation on insects reduces damage to the foliage of cocoa trees (Theobroma cacao) in western Panama. Journal of Tropical Ecology 23:715-719.

Welles, M. (1978). TV tower kill at Elmira. The Kingbird 28:159-161.

Wiltschko, W., U. Munro, H. Ford, and R. Wiltschko. (1993). Red light disrupts magnetic orientation of migratory birds. Nature 364:525.

Wiltschko, W., and R. Wiltschko. (1999). The effect of yellow and blue light on magnetic compass orientation in European robins, Erithacus rubecula. Journal of Comparative Physiology A 184:295-299.

Young, E. A., and M. B. Robbins, eds. (2001). Bird mortality at the KTKA-TV tower, near Topeka, Kansas, 1998-2000 (Grant\# 60181-8-P269). Report to the US Fish and Wildlife Service, Region, 6 . 


\section{APPENDIX A: CORRECTION FACTORS FOR CALCULATING MAXIMUM AND MEAN}

\section{SEASONAL TOWER MORTALITY}

\begin{tabular}{|c|c|c|}
\hline Source & Correction Factor & Notes \\
\hline Anonymous 1961 & +75 unidentified birds & \\
\hline Avery et al. 1978 & $\begin{array}{l}\text { Estimated kill numbers used } \\
\text { instead of number of birds } \\
\text { collected. Decimal } \\
\text { proportions calculated by } \\
\text { number of birds collected / } \\
\text { estimated birds killed. }\end{array}$ & $\begin{array}{l}\text { Fall } 1971 \text { kill number } \\
\text { estimated by dividing number } \\
\text { of collected birds by the } \\
\text { average of decimal } \\
\text { proportions for other seasonal } \\
\text { estimates. }\end{array}$ \\
\hline Brewer and Ellis 1958 & $\begin{array}{l}\text { Number of birds collected / } \\
0.85\end{array}$ & \\
\hline Crawford and Engstrom 2001 & $\begin{array}{l}\text { Number of birds collected in } \\
\text { year without scavenger } \\
\text { control / } 0.29\end{array}$ & $\begin{array}{l}\text { For years without cited } \\
\text { collection range, used } \\
\text { temporal boundaries of thesis } \\
\text { project; for years with cited } \\
\text { collection range, cited range } \\
\text { used. Both allowed } \\
\text { exceptions for early or late } \\
\text { kill dates composing }>50 \\
\text { birds. }\end{array}$ \\
\hline Herron 1997 & $\begin{array}{l}\text { Number of birds collected / } \\
0.5\end{array}$ & \\
\hline Lasky et al. 1960 & +85 unidentified birds & \\
\hline Seets and Bohlen 1977 & $\begin{array}{l}\text { Number of birds collected / } \\
0.7\end{array}$ & \\
\hline Young and Robbins 2000 & $\begin{array}{l}\text { Number of birds collected / } \\
0.5\end{array}$ & \\
\hline
\end{tabular}




\section{APPENDIX B: RADAR STATIONS USED IN BIRD MOVEMENT ANALYSIS}

\begin{tabular}{|l|l|l|l|l|c|}
\hline \multicolumn{1}{|c|}{ Station } & \multicolumn{1}{c|}{ City } & \multicolumn{1}{c|}{ State } & \multicolumn{1}{c|}{ Latitude } & \multicolumn{1}{c|}{ Longitude } & Implementation Date \\
\hline KDVN & Davenport & IA & 41.61167 & -90.58083 & $08 / 17 / 1995$ \\
\hline KILX & Lincoln & IL & 40.15056 & -89.33667 & $09 / 08 / 1995$ \\
\hline KLOT & Chicago & IL & 41.60444 & -88.08472 & $04 / 13 / 1995$ \\
\hline KLSX & St. Louis & MO & 38.69889 & -90.68278 & $08 / 04 / 1992$ \\
\hline KMKX & Milwaukee & WI & 42.96778 & -88.55056 & $05 / 24 / 1995$ \\
\hline KPAH & Paducah & KY & 37.06833 & -88.77194 & $08 / 11 / 1995$ \\
\hline KVWX & Evansville & IN & 38.26 & -87.7247 & $12 / 02 / 2003$ \\
\hline
\end{tabular}


APPENDIX C: WEATHER STATIONS USED IN KRIGING INTERPOLATIONS

\begin{tabular}{|l|l|l|l|}
\hline \multicolumn{1}{|c|}{ Station Name } & State & Latitude & Longitude \\
\hline Albertus Airport & IL & 42.24611 & -89.58222 \\
\hline Bloomington Normal Airport* & IL & 40.48333 & -88.95 \\
\hline Cahokia-St. Louis Downtown Airport & IL & 38.57139 & -90.15722 \\
\hline Cairo Regional Airport & IL & 37.06444 & -89.21944 \\
\hline Carmi Municipal Airport & IL & 38.08944 & -88.12306 \\
\hline Centralia Municipal Airport & IL & 38.51472 & -89.09194 \\
\hline Champaign-University of Illinois Willard Airport & IL & 40.03972 & -88.27778 \\
\hline Chicago Midway Airport & IL & 41.78611 & -87.75222 \\
\hline Danville Vermillion County Airport & IL & 40.2 & -87.6 \\
\hline Decatur Airport & IL & 39.83444 & -88.86556 \\
\hline DeKalb Taylor Municipal Airport & IL & 41.93167 & -88.70806 \\
\hline DuPage Airport & IL & 41.91444 & -88.24639 \\
\hline Effingham County Memorial Airport & IL & 39.07028 & -88.53333 \\
\hline Fairfield Municipal Airport & IL & 38.37861 & -88.4125 \\
\hline Flora Municipal Airport & IL & 38.66472 & -88.45278 \\
\hline Galesburg Municipal Airport & IL & 40.93333 & -90.43333 \\
\hline Greater Kankakee Airport & IL & 41.12139 & -87.84611 \\
\hline Greater Peoria Regional Airport & IL & 40.6675 & -89.6839 \\
\hline Greater Rockford Airport & IL & 42.1927 & -89.093 \\
\hline Harrisburg-Raleigh Airport & IL & 37.81139 & -88.54889 \\
\hline Jacksonville Municipal Airport & IL & 39.77972 & -90.23833 \\
\hline Joliet Regional Airport & IL & 41.5 & -88.16667 \\
\hline Lincoln Logan County Airport & IL & 40.15833 & -89.33472 \\
\hline Litchfield Municipal Airport & IL & 39.1625 & -89.67472 \\
\hline Macomb Municipal Airport & IL & 40.52028 & -90.65222 \\
\hline Marion Williamson County Airport & IL & 37.75 & -89 \\
\hline Mattoon-Charleston Coles County Airport & IL & 39.47806 & -88.28028 \\
\hline Metropolis Airport* & IL & 37.18583 & -88.75056 \\
\hline Morris Municipal Airport & IL & 41.42528 & -88.41861 \\
\hline Mt. Carmel Municipal Airport & IL & 38.60667 & -87.72667 \\
\hline Mt. Vernon Outland Airport* & IL & 38.32333 & -88.85833 \\
\hline Olney-Noble Airport & IL & 38.72167 & -88.17639 \\
\hline
\end{tabular}




\begin{tabular}{|l|l|l|l|}
\hline Peru Illinois Valley Regional Airport & IL & 41.35167 & -89.15306 \\
\hline Pittsfield Penstone Municipal Airport & IL & 39.63861 & -90.77833 \\
\hline Pontiac Municipal Airport & IL & 40.92361 & -88.62528 \\
\hline Quad City International Airport & IL & 41.46528 & -90.52333 \\
\hline Quincy Regional Airport* & IL & 39.93694 & -91.19194 \\
\hline Rantoul National Aviation Center & IL & 40.29333 & -88.14222 \\
\hline Robinson Municipal Airport & IL & 39.01611 & -87.64972 \\
\hline Rochelle Municipal Koritz Field Airport & IL & 41.89278 & -89.07806 \\
\hline Salem Leckrone Airport & IL & 38.65 & -88.96667 \\
\hline Sparta Community Hunter Field Airport & IL & 38.14889 & -89.69861 \\
\hline Springfield- Abraham Lincoln Capitol Airport & IL & 39.8447 & -89.6839 \\
\hline Sterling-Rock Falls Whiteside County Airport* & IL & 41.74278 & -89.67611 \\
\hline Taylorville Municipal Airport & IL & 39.53417 & -89.32778 \\
\hline Tri Township Airport & IL & 42.04583 & -90.10806 \\
\hline Davenport Municipal Airport & IA & 41.61389 & -90.5913 \\
\hline Dubuque Regional Airport & IA & 42.39778 & -90.70361 \\
\hline Mt. Pleasant Municipal Airport & IA & 40.94667 & -91.51111 \\
\hline Evansville Regional Airport & IN & 38.0441 & -87.5205 \\
\hline Gary & IN & 41.61667 & -87.41667 \\
\hline Purdue University Airport & IN & 40.41222 & -86.93694 \\
\hline Terre Haute Regional Airport & IN & 39.45194 & -87.30889 \\
\hline Madisonville Municipal Airport* & KY & 37.35 & -87.4 \\
\hline Paducah Barkley Regional Airport & KY & 37.0563 & -88.7744 \\
\hline Farmington Regional Airport* & MO & 37.76083 & -90.42833 \\
\hline Hannibal Regional Airport & MO & 39.72516 & -91.44386 \\
\hline Poplar Bluff Municipal Airport & MO & 36.7725 & -90.32472 \\
\hline St. Louis Lambert International Airport & MO & 38.7525 & -90.3736 \\
\hline Janesville Rock County & WI & 42.61667 & -89.03333 \\
\hline Kenosha Regional Airport & WI & 42.595 & -87.93806 \\
\hline Platteville Municipal Airport & WI & 42.683 & -90.45 \\
\hline & & & \\
\hline
\end{tabular}

* Indicates partial use of anomalous sampling times at 4:00 UTC in place of 5:00 UTC due to deficient data in Fall 2016, Spring 2017, or both. 


\section{APPENDIX D: SOURCES AND LINKS FOR GIS SPATIAL DATA}

\begin{tabular}{|c|c|c|c|}
\hline Data & Source & Format & Links \\
\hline $\begin{array}{l}\text { Illinois State } \\
\text { Boundaries }\end{array}$ & $\begin{array}{l}\text { United States Census } \\
\text { Bureau }\end{array}$ & Shapefile & $\begin{array}{l}\text { https://www.isgs.illin } \\
\text { ois.edu/research/coal/ } \\
\underline{\text { shapefiles }}\end{array}$ \\
\hline Illinois Counties & $\begin{array}{l}\text { United States Census } \\
\text { Bureau }\end{array}$ & Shapefile & $\begin{array}{l}\text { https://www.isgs.illin } \\
\text { ois.edu/research/coal/ } \\
\text { shapefiles }\end{array}$ \\
\hline Tower Attributes & $\begin{array}{l}\text { Federal } \\
\text { Communications } \\
\text { Commission }\end{array}$ & Point feature class & $\begin{array}{l}\text { Courtesy of Dr. Joelle } \\
\text { Gehring, FCC. }\end{array}$ \\
\hline $\begin{array}{l}\text { Weather } \\
\text { Observations }\end{array}$ & $\begin{array}{l}\text { National Oceanic and } \\
\text { Atmospheric } \\
\text { Administration }\end{array}$ & $\begin{array}{l}\text { Point feature } \\
\text { class, Kriging } \\
\text { interpolation } \\
\text { rasters }\end{array}$ & $\begin{array}{l}\text { https://www7.ncdc.no } \\
\text { aa.gov/CDO/cdopoe } \\
\text { main.cmd?datasetabb } \\
\text { v=DS3505\&countrya } \\
\text { bbv=\&georegionabbv } \\
=\text { \&resolution }=40\end{array}$ \\
\hline Bird Movement & $\begin{array}{l}\text { National Oceanic and } \\
\text { Atmospheric } \\
\text { Administration }\end{array}$ & NEXRAD radar files & $\begin{array}{l}\text { https://www.ncdc.noa } \\
\text { a.gov/cdo- } \\
\text { web/datatools/selectl } \\
\text { ocation } \\
\text { https://gis.ncdc.noaa. } \\
\text { gov/maps/ncei/radar }\end{array}$ \\
\hline $\begin{array}{l}\text { Weather and Climate } \\
\text { Toolkit Software }\end{array}$ & $\begin{array}{l}\text { National Oceanic and } \\
\text { Atmospheric } \\
\text { Administration }\end{array}$ & $\begin{array}{l}\text { Free Downloadable } \\
\text { Toolkit Software }\end{array}$ & $\begin{array}{l}\text { https://www.ncdc.noa } \\
\text { a.gov/wct/ }\end{array}$ \\
\hline
\end{tabular}


APPENDIX E: ANOMALOUS SAMPLING TIMES USED FOR EASTERN UNITED

STATES TOWER WEATHER

\begin{tabular}{|c|c|c|c|c|c|}
\hline Tower & $\begin{array}{l}\text { Weather } \\
\text { Station }\end{array}$ & \begin{tabular}{|l|} 
Weather \\
Station \\
Latitude \\
\end{tabular} & $\begin{array}{l}\text { Weather } \\
\text { Station } \\
\text { Longitude }\end{array}$ & $\begin{array}{l}\text { Time used } \\
\text { (UTC) }\end{array}$ & Years used \\
\hline $\begin{array}{l}\text { WCTV (90 } \\
\text { m) }\end{array}$ & $\begin{array}{l}\text { Tallahassee } \\
\text { Regional } \\
\text { Airport }\end{array}$ & 30.39306 & -84.35333 & 06:00 & 1 \\
\hline $\begin{array}{l}\text { WSIX } \\
\text { (WKRN) }\end{array}$ & $\begin{array}{l}\text { Nashville } \\
\text { International } \\
\text { Airport }\end{array}$ & \begin{tabular}{|l|l|}
36.11889 \\
\end{tabular} & -86.68917 & 06:00 & 4 \\
\hline WSMV & $\begin{array}{l}\text { Nashville } \\
\text { International } \\
\text { Airport }\end{array}$ & 36.11889 & -86.68917 & $06: 00$ & 19 \\
\hline WCHS-TV & $\begin{array}{l}\text { Charleston } \\
\text { Kanawha } \\
\text { Airport/ } \\
\text { Yeager } \\
\text { Airport }\end{array}$ & 38.3794 & -81.59 & 06:00 & 3 \\
\hline $\begin{array}{l}\text { WCTV (308 } \\
\text { m) }\end{array}$ & $\begin{array}{l}\text { Tallahassee } \\
\text { Regional } \\
\text { Airport }\end{array}$ & 30.39306 & -84.35333 & 06:00 & 10 \\
\hline KROC & $\begin{array}{l}\text { Rochester } \\
\text { Municipal } \\
\text { Airport/ } \\
\text { Rochester } \\
\text { International } \\
\text { Airport }\end{array}$ & 43.9041 & -92.4916 & 06:00 & 1 \\
\hline WSMW & $\begin{array}{l}\text { Worcester } \\
\text { Municipal } \\
\text { Airport }\end{array}$ & 42.2706 & -71.8731 & $06: 00$ & 2 \\
\hline $\begin{array}{l}\text { WDBO- } \\
\text { WFTV }\end{array}$ & $\begin{array}{l}\text { Orlando } \\
\text { Municipal } \\
\text { Airport }\end{array}$ & 28.546 & -81.332 & 06:00 & 1 \\
\hline KDIN-TV & $\begin{array}{l}\text { Ankeny } \\
\text { Regional } \\
\text { Airport }\end{array}$ & 41.691 & -93.566 & 03:00, 06:00 & 3 \\
\hline
\end{tabular}


APPENDIX F: ANOMALOUS SAMPLING TIMES USED FOR ILLINOIS TOWER

WEATHER

\begin{tabular}{|l|l|l|l|l|l|}
\hline Tower & $\begin{array}{l}\text { Weather } \\
\text { Station }\end{array}$ & $\begin{array}{l}\text { Weather } \\
\text { Station } \\
\text { Latitude }\end{array}$ & $\begin{array}{l}\text { Weather } \\
\text { Station } \\
\text { Longitude }\end{array}$ & $\begin{array}{l}\text { Time used } \\
\text { (UTC) }\end{array}$ & Years used \\
\hline WEEK & $\begin{array}{l}\text { Greater } \\
\text { Peoria } \\
\text { Regional } \\
\text { Airport }\end{array}$ & 40.6675 & -89.6839 & $06: 00$ & 1 \\
\hline WRSP-TV & $\begin{array}{l}\text { Springfield- } \\
\text { Abraham } \\
\text { Lincoln } \\
\text { Capitol } \\
\text { Airport }\end{array}$ & 39.8447 & -89.6839 & $06: 00$ & 4 \\
\hline $\begin{array}{l}\text { WICS (304 } \\
\text { m) }\end{array}$ & $\begin{array}{l}\text { Springfield- } \\
\text { Abraham } \\
\text { Lincoln } \\
\text { Capitol } \\
\text { Airport }\end{array}$ & 39.8447 & -89.6839 & $06: 00$ & 4 \\
\hline $\begin{array}{l}\text { WICS (444 } \\
\text { m) }\end{array}$ & $\begin{array}{l}\text { Springfield- } \\
\text { Abraham } \\
\text { Lincoln } \\
\text { Capitol } \\
\text { Airport }\end{array}$ & 39.8447 & -89.6839 & $06: 00$ & 6 \\
\hline
\end{tabular}




\section{TABLES}

Table 1: Eigenvalues for Eastern United States Tower Principal Component Analysis

\begin{tabular}{|l|r|r|r|r|}
\hline & Eigenvalue & Difference & Proportion & Cumulative \\
\hline $\mathbf{1}$ & 1.97666572 & 0.61675622 & 0.3953 & 0.3953 \\
\hline $\mathbf{2}$ & 1.35990951 & 0.56107769 & 0.2720 & 0.6673 \\
\hline $\mathbf{3}$ & 0.79883182 & 0.07239602 & 0.1598 & 0.8271 \\
\hline $\mathbf{4}$ & 0.72643580 & 0.58827865 & 0.1453 & 0.9724 \\
\hline $\mathbf{5}$ & 0.13815715 & & 0.0276 & 1.0000 \\
\hline
\end{tabular}

Table 2: Rotated Factor Patterns for Eastern United States Tower Principal Component Analysis

\begin{tabular}{|l|r|r|r|}
\hline & Tower Factor 1 & Tower Factor 2 & Tower Factor 3 \\
\hline Elevation & $82^{*}$ & -12 & 5 \\
\hline Height & $-67^{*}$ & 1 & $55^{*}$ \\
\hline Wire Sets & -1 & -3 & $92^{*}$ \\
\hline $\begin{array}{l}\text { Steady } \\
\text { Lights }\end{array}$ & -32 & $90^{*}$ & 10 \\
\hline $\begin{array}{l}\text { Flashing } \\
\text { Lights }\end{array}$ & $-54^{*}$ & $-72^{*}$ & 33 \\
\hline
\end{tabular}

Printed values are multiplied by 100 and rounded to the nearest integer. Absolute values greater than 40 are flagged by an '*'.

Table 3: Eigenvalues for Eastern United States Weather Principal Component Analysis

\begin{tabular}{|l|r|r|r|r|}
\hline & Eigenvalue & Difference & Proportion & Cumulative \\
\hline $\mathbf{1}$ & 2.98615980 & 1.63949050 & 0.4977 & 0.4977 \\
\hline $\mathbf{2}$ & 1.34666930 & 0.56179804 & 0.2244 & 0.7221 \\
\hline $\mathbf{3}$ & 0.78487126 & 0.08040135 & 0.1308 & 0.8530 \\
\hline $\mathbf{4}$ & 0.70446991 & 0.55310888 & 0.1174 & 0.9704 \\
\hline $\mathbf{5}$ & 0.15136103 & 0.12489234 & 0.0252 & 0.9956 \\
\hline $\mathbf{6}$ & 0.02646869 & & 0.0044 & 1.0000 \\
\hline
\end{tabular}


Table 4: Rotated Factor Patterns for Eastern United States Weather Principal Component

Analysis

\begin{tabular}{|l|r|r|r|r|}
\hline & $\begin{array}{r}\text { Weather } \\
\text { Factor 1 }\end{array}$ & $\begin{array}{r}\text { Weather } \\
\text { Factor 2 }\end{array}$ & $\begin{array}{r}\text { Weather } \\
\text { Factor 3 }\end{array}$ & $\begin{array}{r}\text { Weather } \\
\text { Factor 4 }\end{array}$ \\
\hline Wind Speed & 24 & 3 & $97^{*}$ & 9 \\
\hline Wind Direction & -2 & $98^{*}$ & 3 & 14 \\
\hline Cloud Cover & $90^{*}$ & -31 & 22 & 7 \\
\hline Cloud Ceiling & $-91^{*}$ & -20 & -15 & -8 \\
\hline $\begin{array}{l}\text { \% Favorable } \\
\text { Wind Days }\end{array}$ & 10 & 14 & 9 & $98^{*}$ \\
\hline $\begin{array}{l}\text { \% Overcast } \\
\text { Days }\end{array}$ & $97^{*}$ & 0 & 11 & 6 \\
\hline
\end{tabular}

Printed values are multiplied by 100 and rounded to the nearest integer. Values greater than 40 are flagged by an '*'.

Table 5: Eigenvalues for Illinois Tower Principal Component Analysis

\begin{tabular}{|l|r|r|r|r|}
\hline & Eigenvalue & Difference & Proportion & Cumulative \\
\hline $\mathbf{1}$ & 1.97659670 & 0.46547264 & 0.3953 & 0.3953 \\
\hline $\mathbf{2}$ & 1.51112406 & 0.73968611 & 0.3022 & 0.6975 \\
\hline $\mathbf{3}$ & 0.77143795 & 0.21732977 & 0.1543 & 0.8518 \\
\hline $\mathbf{4}$ & 0.55410818 & 0.36737507 & 0.1108 & 0.9627 \\
\hline $\mathbf{5}$ & 0.18673311 & & 0.0373 & 1.0000 \\
\hline
\end{tabular}

Table 6: Rotated Factor Patterns for Illinois Tower Principal Component Analysis

\begin{tabular}{|l|r|r|r|}
\hline & Tower Factor 1 & Tower Factor 2 & Tower Factor 3 \\
\hline Elevation & -22 & $-83^{*}$ & 8 \\
\hline Height & -22 & $81^{*}$ & 25 \\
\hline Wire Sets & -12 & 7 & $97^{*}$ \\
\hline Steady Lights & $90^{*}$ & 26 & 1 \\
\hline Flashing Lights & $-85^{*}$ & 31 & 30 \\
\hline
\end{tabular}

Printed values are multiplied by 100 and rounded to the nearest integer. Values greater than 40 are flagged by an '*'. 
Table 7: Eigenvalues for Illinois Weather Principal Component Analysis

\begin{tabular}{|l|r|r|r|r|}
\hline & Eigenvalue & Difference & Proportion & Cumulative \\
\hline $\mathbf{1}$ & 3.50202758 & 2.37027535 & 0.5837 & 0.5837 \\
\hline $\mathbf{2}$ & 1.13175223 & 0.32609336 & 0.1886 & 0.7723 \\
\hline $\mathbf{3}$ & 0.80565886 & 0.39685356 & 0.1343 & 0.9066 \\
\hline $\mathbf{4}$ & 0.40880530 & 0.26029921 & 0.0681 & 0.9747 \\
\hline $\mathbf{5}$ & 0.14850610 & 0.14525617 & 0.0248 & 0.9995 \\
\hline $\mathbf{6}$ & 0.00324993 & & 0.0005 & 1.0000 \\
\hline
\end{tabular}

Table 8: Rotated Factor Patterns for Illinois Weather Principal Component Analysis

\begin{tabular}{|c|c|c|c|c|}
\hline & $\begin{array}{r}\text { Weather Factor } \\
1 \\
\end{array}$ & $\begin{array}{r}\text { Weather Factor } \\
2 \\
\end{array}$ & $\begin{array}{r}\text { Weather Factor } \\
3 \\
\end{array}$ & $\begin{array}{r}\text { Weather Factor } \\
4\end{array}$ \\
\hline Wind Speed & 36 & -26 & 17 & 87 \\
\hline Wind Direction & -22 & 94* & 10 & -20 \\
\hline Cloud Cover & $95^{*}$ & -18 & -2 & 24 \\
\hline Cloud Ceiling & $-89^{*}$ & 1 & 7 & -37 \\
\hline $\begin{array}{l}\text { \% Favorable } \\
\text { Wind Days }\end{array}$ & -4 & 8 & $99^{*}$ & 11 \\
\hline $\begin{array}{l}\text { \% Overcast } \\
\text { Days }\end{array}$ & $92 *$ & -31 & 1 & \\
\hline
\end{tabular}

Printed values are multiplied by 100 and rounded to the nearest integer. Values greater than 40 are flagged by an '*'.

Table 9: Stepwise Selection Summary for Eastern United States Towers, Fall

\begin{tabular}{|r|l|r|r|r|r|r|r|}
\hline Step & $\begin{array}{l}\text { Effect } \\
\text { Entered }\end{array}$ & $\begin{array}{r}\text { Model } \\
\text { R-Square }\end{array}$ & $\begin{array}{r}\text { Adjusted } \\
\text { R-Square }\end{array}$ & AIC & AICC & F Value & Pr > F \\
\hline $\mathbf{0}$ & Intercept & 0.0000 & 0.0000 & 30.0993 & 30.5279 & 0.00 & 1.0000 \\
\hline $\mathbf{1}$ & $\begin{array}{l}\text { Tower } \\
\text { Factor 1 }\end{array}$ & 0.1823 & $0.1541^{*}$ & $25.8608^{*}$ & $26.7497^{*}$ & 6.46 & 0.0166 \\
\hline
\end{tabular}

* Optimal Value of Criterion 
Table 10: Stepwise Multiple Regression Parameter Estimates for Eastern United States

Towers, Fall

\begin{tabular}{|l|r|r|r|r|}
\hline Parameter & DF & Estimate & $\begin{array}{r}\text { Standard } \\
\text { Error }\end{array}$ & t Value \\
\hline Intercept & 1 & 1.805168 & 0.157237 & 11.48 \\
\hline Tower Factor 1 & 1 & -0.449017 & 0.176598 & -2.54 \\
\hline
\end{tabular}

Table 11: Stepwise Selection Summary for Eastern United States Towers, Spring

\begin{tabular}{|r|l|r|r|r|r|r|r|}
\hline Step & $\begin{array}{l}\text { Effect } \\
\text { Entered }\end{array}$ & $\begin{array}{r}\text { Model } \\
\text { R-Square }\end{array}$ & $\begin{array}{r}\text { Adjusted } \\
\text { R-Square }\end{array}$ & AIC & AICC & $\begin{array}{r}\text { F } \\
\text { Value }\end{array}$ & Pr > F \\
\hline 0 & Intercept & 0.0000 & 0.0000 & 6.4727 & 7.2227 & 0.00 & 1.0000 \\
\hline 1 & Tower Factor 1 & 0.1951 & 0.1478 & 4.3488 & 5.9488 & 4.12 & 0.0583 \\
\hline $\mathbf{2}$ & Weather Factor 3 & 0.3788 & $0.3011^{*}$ & $1.4273^{*}$ & $4.2845^{*}$ & 4.73 & 0.0450 \\
\hline
\end{tabular}

* Optimal Value of Criterion

Table 12: Stepwise Multiple Regression Parameter Estimates for Eastern United States

Towers, Spring

\begin{tabular}{|l|r|r|r|r|}
\hline Parameter & DF & Estimate & $\begin{array}{r}\text { Standard } \\
\text { Error }\end{array}$ & t Value \\
\hline Intercept & 1 & 1.235111 & 0.130031 & 9.50 \\
\hline Tower Factor 1 & 1 & -0.473093 & 0.152331 & -3.11 \\
\hline Weather Factor 3 & 1 & -0.324352 & 0.149127 & -2.17 \\
\hline
\end{tabular}

Table 13: Stepwise Selection Summary for Illinois Towers, Fall

\begin{tabular}{|r|l|r|r|r|r|r|r|}
\hline Step & $\begin{array}{l}\text { Effect } \\
\text { Entered }\end{array}$ & $\begin{array}{r}\text { Model } \\
\text { R-Square }\end{array}$ & $\begin{array}{r}\text { Adjusted } \\
\text { R-Square }\end{array}$ & AIC & AICC & F Value & Pr > F \\
\hline $\mathbf{0}$ & Intercept & 0.0000 & 0.0000 & 0.4073 & 1.7406 & 0.00 & 1.0000 \\
\hline $\mathbf{1}$ & $\begin{array}{l}\text { Light } \\
\text { Color }\end{array}$ & 0.4991 & $0.4490^{*}$ & $-5.8895^{*}$ & $-2.8895^{*}$ & 9.97 & 0.0102 \\
\hline
\end{tabular}

* Optimal Value of Criterion 
Table 14: Stepwise Multiple Regression Parameter Estimates for Illinois Towers, Fall

\begin{tabular}{|l|r|r|r|r|}
\hline Parameter & DF & Estimate & $\begin{array}{r}\text { Standard } \\
\text { Error }\end{array}$ & t Value \\
\hline Intercept & 1 & 0.620481 & 0.233741 & 2.65 \\
\hline $\begin{array}{l}\text { Light Color } \\
\text { Red }\end{array}$ & 1 & 0.852008 & 0.269901 & 3.16 \\
\hline $\begin{array}{l}\text { Light Color } \\
\text { White }\end{array}$ & 0 & 0 & - & - \\
\hline
\end{tabular}

Table 15: Stepwise Selection Summary for Illinois Towers, Spring

\begin{tabular}{|r|l|r|r|r|r|r|r|}
\hline Step & $\begin{array}{l}\text { Effect } \\
\text { Entered }\end{array}$ & $\begin{array}{r}\text { Model } \\
\text { R-Square }\end{array}$ & $\begin{array}{r}\text { Adjusted } \\
\text { R-Square }\end{array}$ & AIC & AICC & F Value & Pr > F \\
\hline $\mathbf{0}$ & Intercept & 0.0000 & 0.0000 & -0.9853 & $3.0147^{*}$ & 0.00 & 1.0000 \\
\hline $\mathbf{1}$ & $\begin{array}{l}\text { Weather } \\
\text { Factor 1 }\end{array}$ & 0.5882 & 0.4852 & -4.3083 & 7.6917 & 5.71 & 0.0752 \\
\hline $\mathbf{2}$ & $\begin{array}{l}\text { Weather } \\
\text { Factor 3 }\end{array}$ & 0.9310 & $0.8851^{*}$ & $-13.0305^{*}$ & 26.9695 & 14.92 & 0.0307 \\
\hline
\end{tabular}

* Optimal Value of Criterion

Table 16: Stepwise Multiple Regression Parameter Estimates for Illinois Towers, Spring

\begin{tabular}{|l|r|r|r|r|}
\hline Parameter & DF & Estimate & $\begin{array}{r}\text { Standard } \\
\text { Error }\end{array}$ & t Value \\
\hline Intercept & 1 & 0.685371 & 0.063533 & 10.79 \\
\hline $\begin{array}{l}\text { Weather Factor } \\
\mathbf{1}\end{array}$ & 1 & -0.423581 & 0.067170 & -6.31 \\
\hline $\begin{array}{l}\text { Weather Factor } \\
\mathbf{3}\end{array}$ & 1 & -0.298491 & 0.077289 & -3.86 \\
\hline
\end{tabular}




\section{FIGURES}

Figure 1: Examples of Weather Stations and Kriging Interpolation in ArcGIS
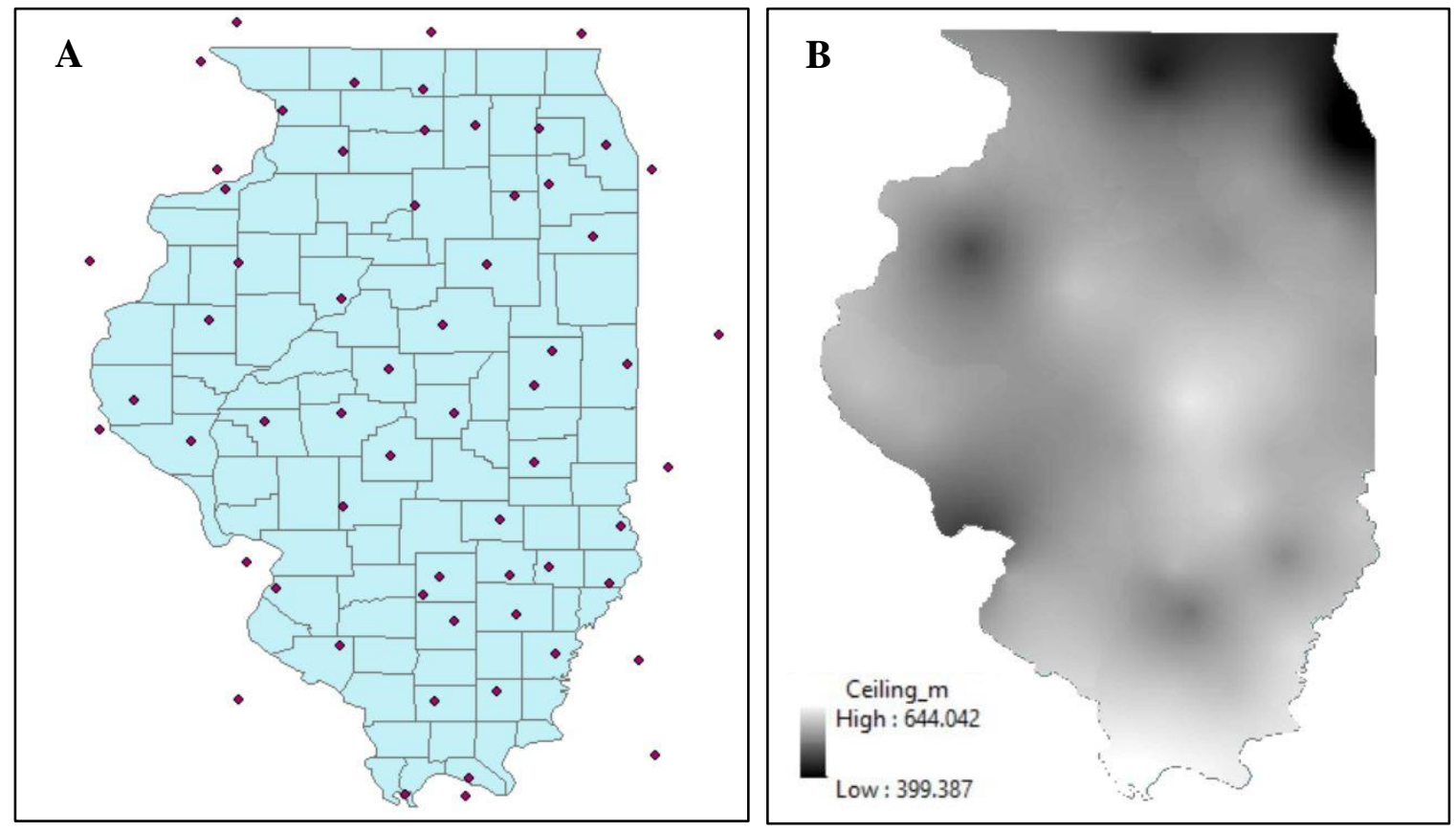

Examples of the point feature class for the 62 weathers stations used in interpolation (A) and the results of a Kriging interpolation in ArcGIS (B). The selection of weather stations included 46 from Illinois and 16 from neighboring states to ensure a complete interpolation across the entire state. 

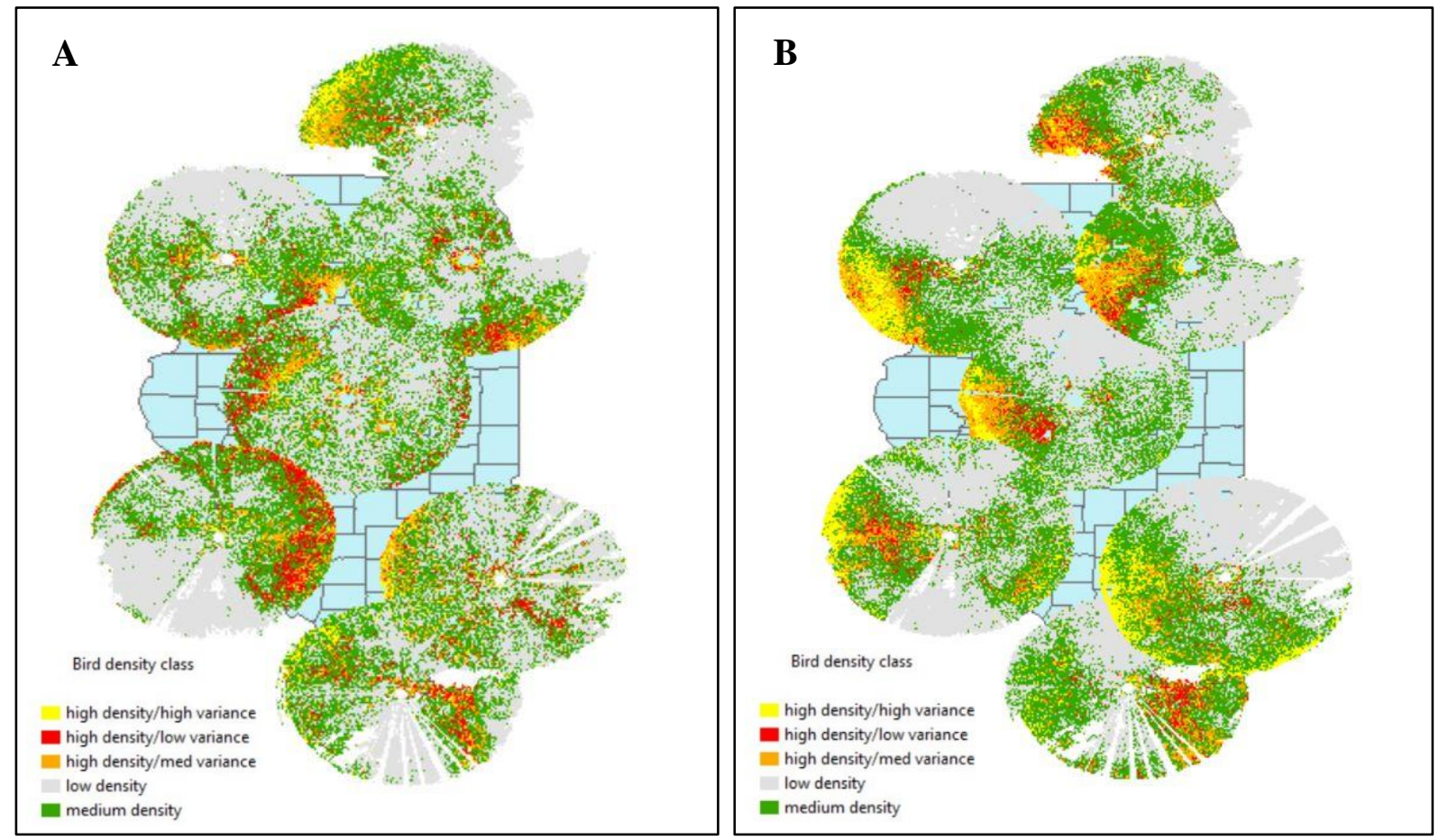

Classified bird densities for KDVN, KILX, KLOT, KLSX, KMKX, KPAH and KVWX radars in Fall 2016 (A) and Spring 2017 (B). Range bias to the west of radar stations occurred in six of seven radars in Spring 2017. 
Figure 3: Log Mean Mortality of Eastern United States Towers, Fall

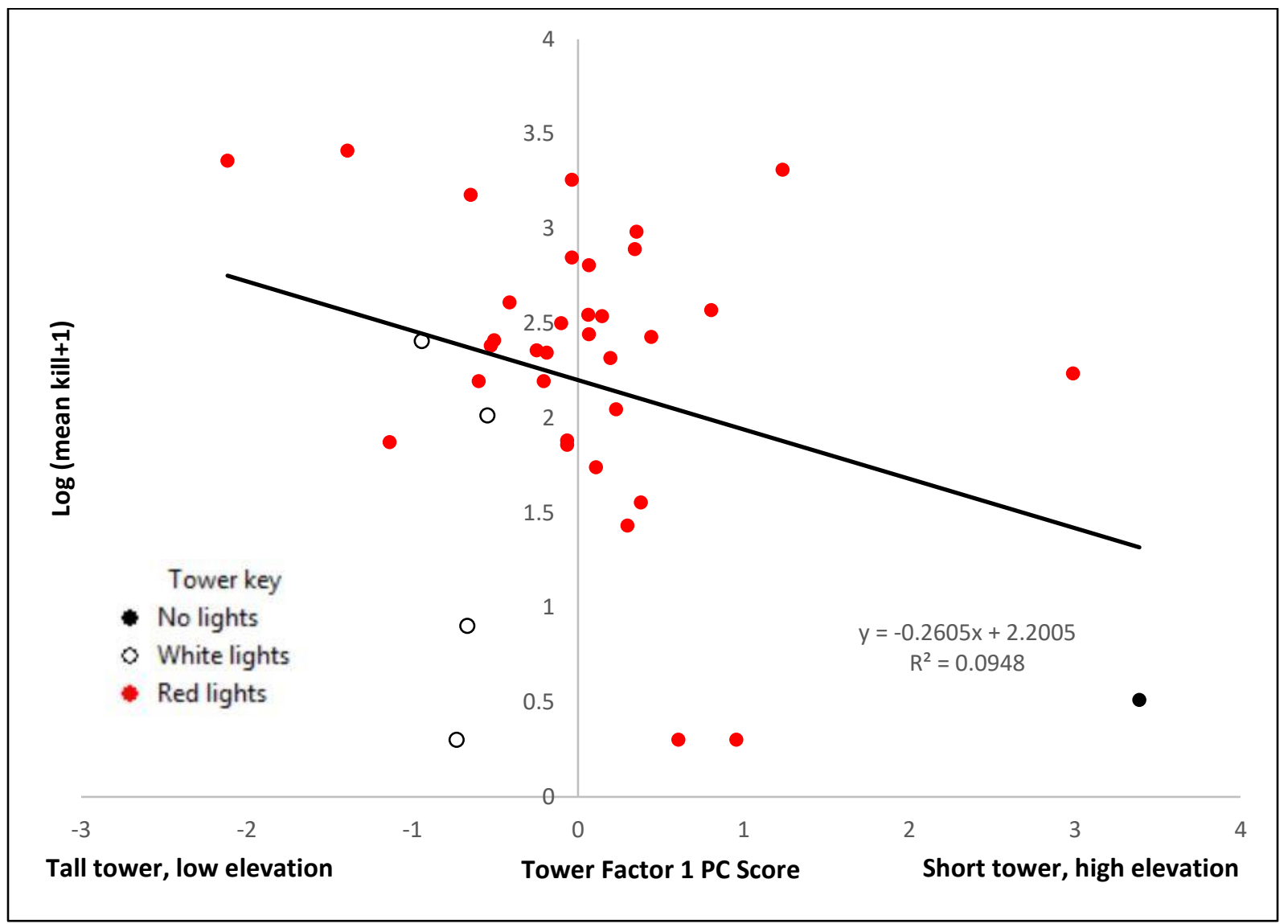

Log-transformed mean tower kills were higher for most towers with red lights than for towers with white lights or the unlit tower included in analysis. A loose negative trend in the first tower factor (land elevation and tower height, where elevation was positive and tower height was negative in the Principal Component Analysis) indicated higher mortality at taller towers. 
Figure 4: Log Mean Mortality of Eastern United States Towers, Spring

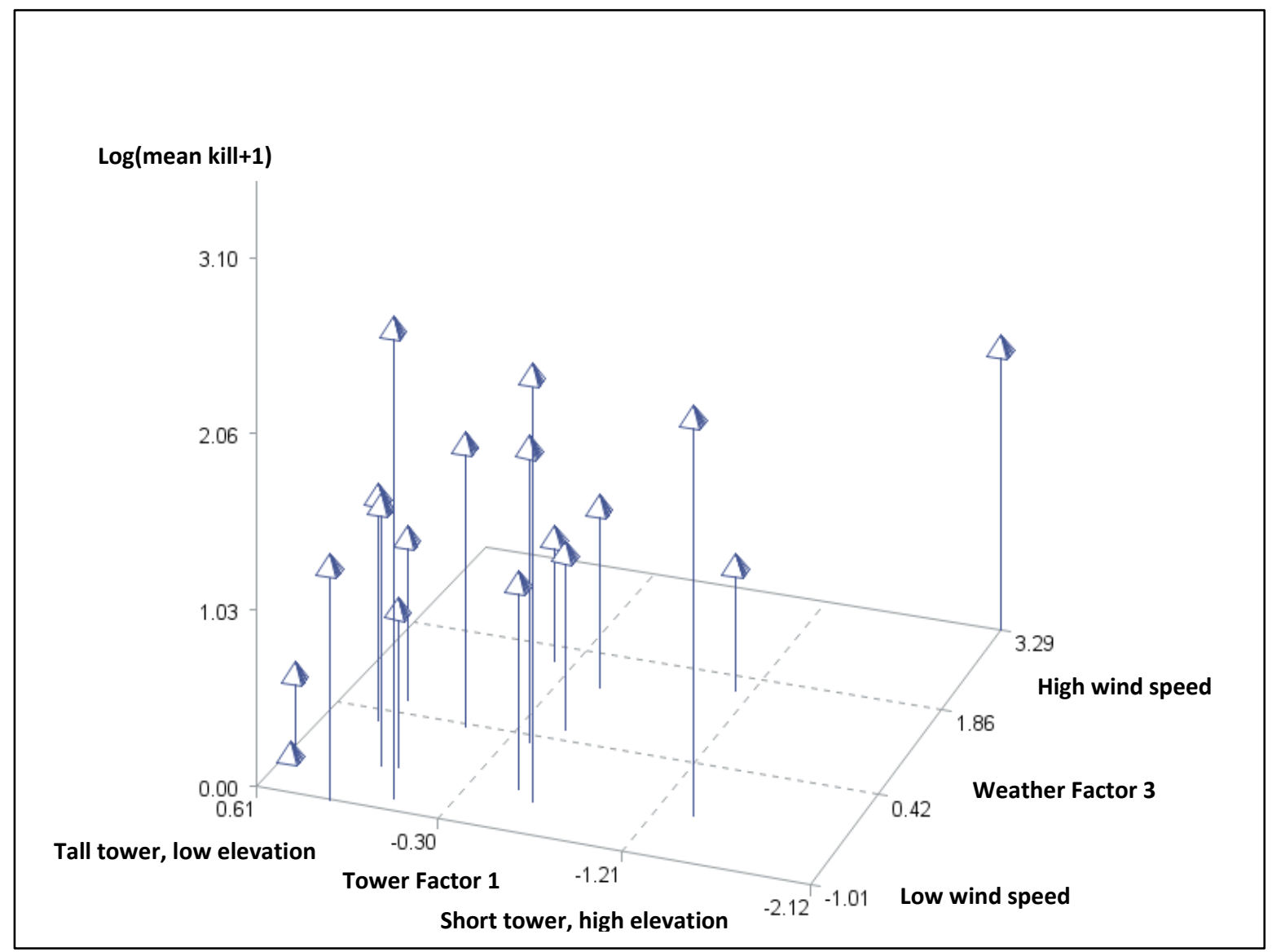

Three-dimensional scatter plot of the first tower factor (land elevation and tower height) and the third weather factor (average wind speed). 
Figure 5: Corrected Residuals for Mean Reflectivity (MN) of Five Radars in Illinois

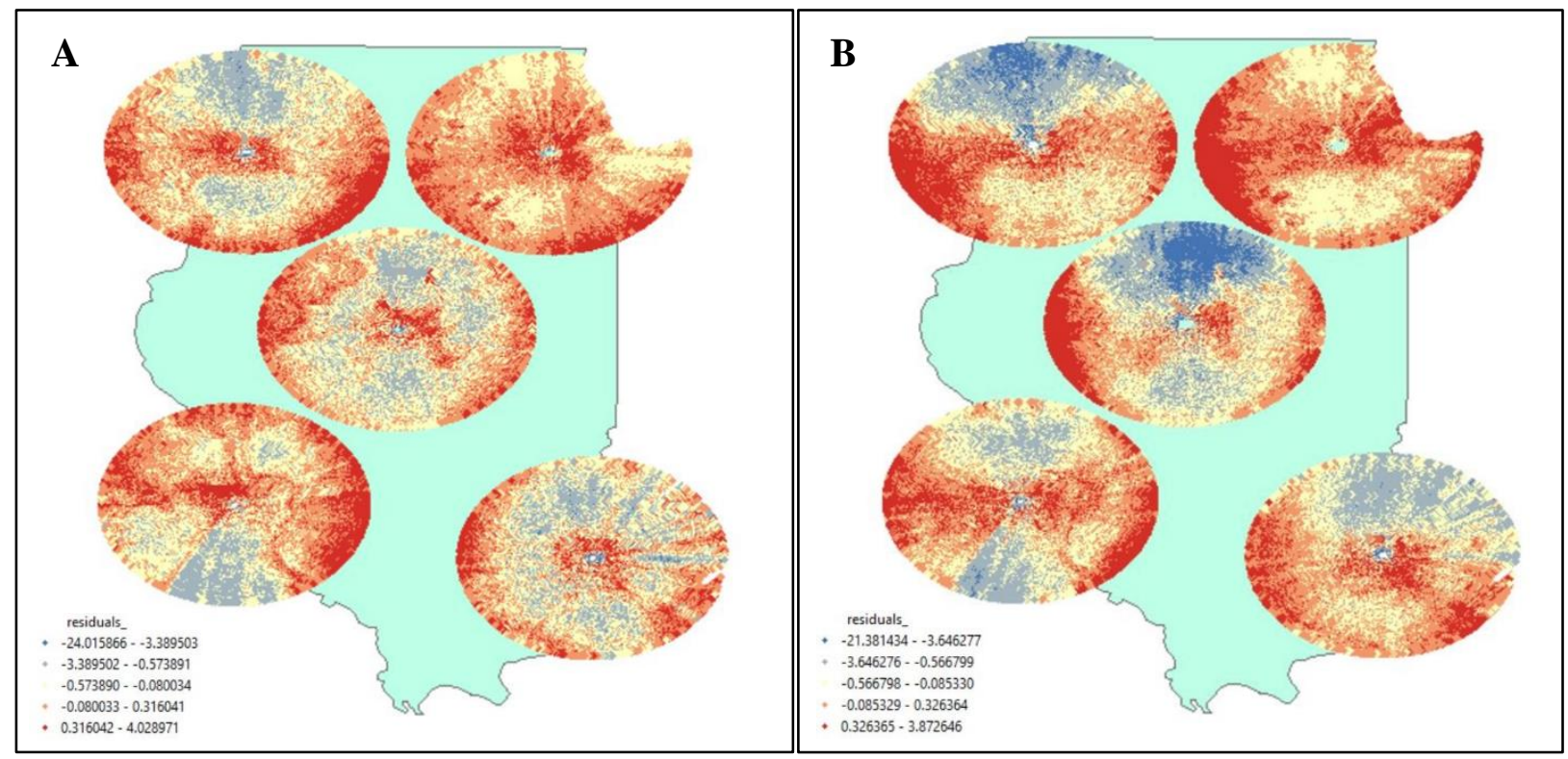

Residuals of mean reflectivity for the KDVN, KILX, KLOT, KLSX, and KVWX radar stations for Fall 2016 (A) and Spring 2017 (B). Lake Michigan constituted a hotspot in spring, but not as strongly in the fall, and most high residuals appeared around the outer extent of radar coverage consistent with peak migration altitude of nocturnally migrating passerines at a sample time of 5:30 UTC. High positive residuals are in red, and high negative residuals are in blue. 
Figure 6: Avian Mortality Risk Indices for Towers Within Coverage of Five Illinois Radars in Fall
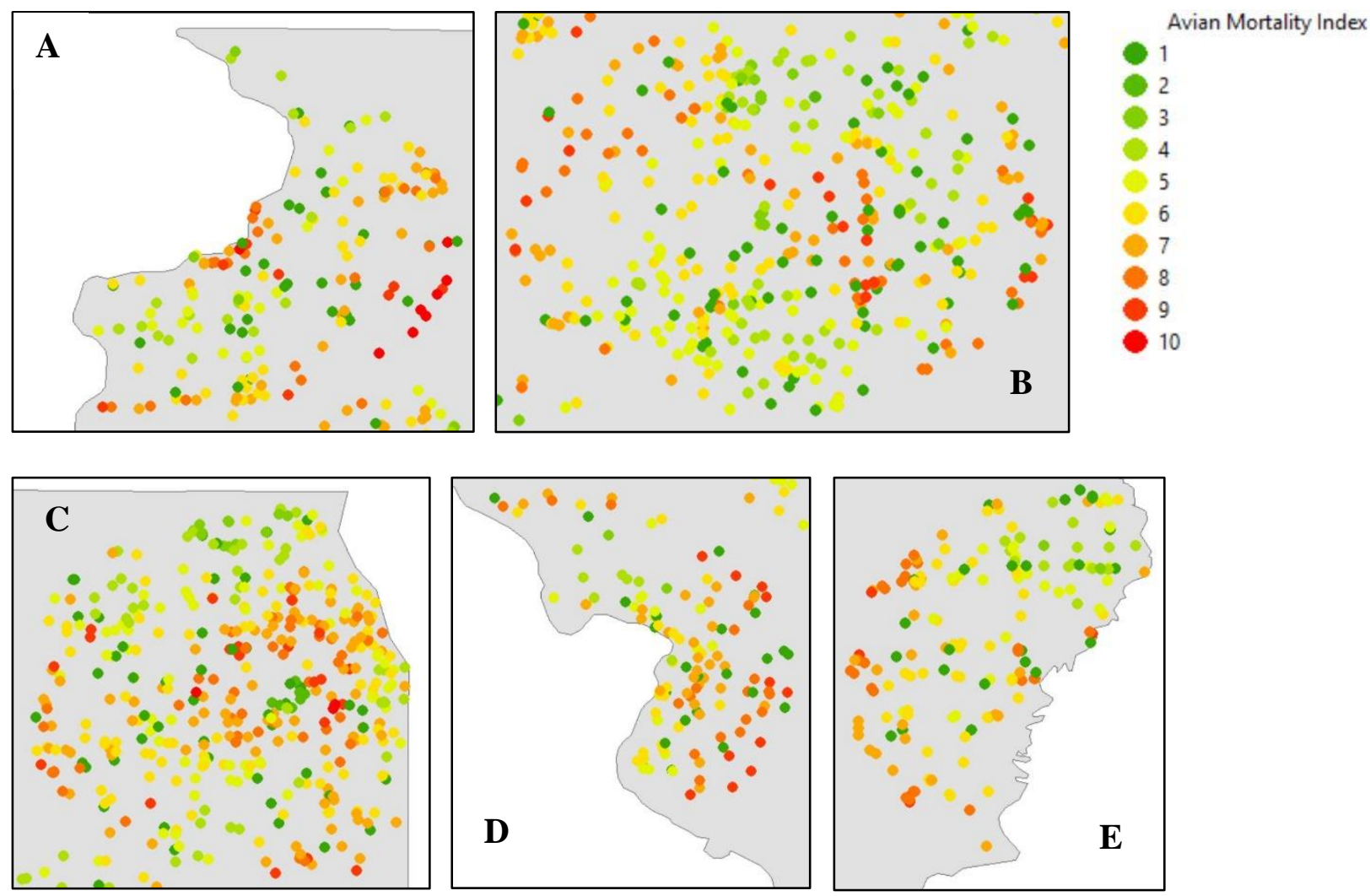

Avian mortality indices for 1-km tower buffers zones within coverage of KDVN (A), KILX (B), KLOT (C), KLSX (D), and KVWX (E) for Fall 2016. Indices are ranked 1-10 from green to red. 
Figure 7: Avian Mortality Risk Indices for Towers Within Coverage of Five Illinois Radars in

\section{Spring}
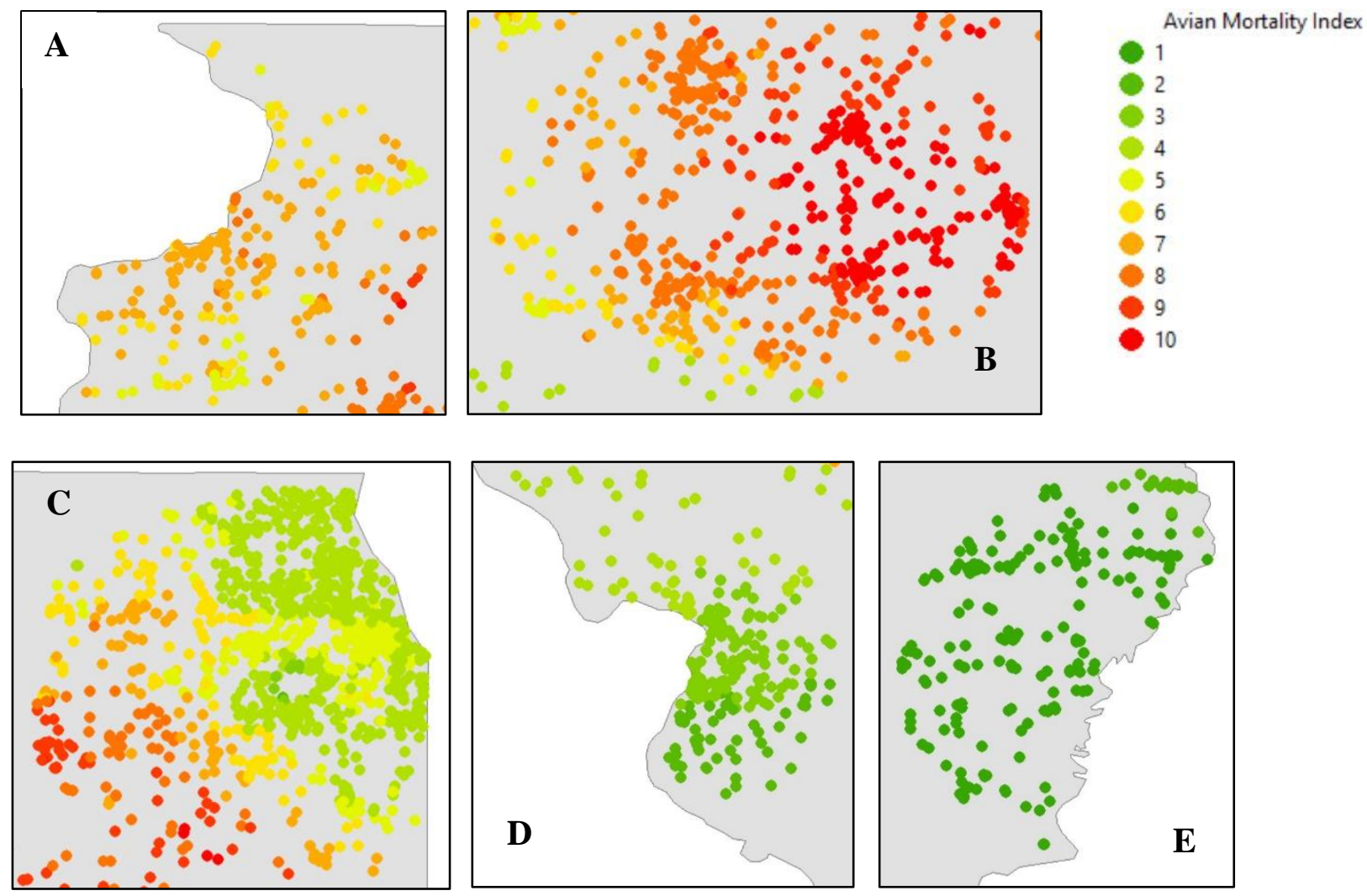

Avian mortality indices for 1-km tower buffers zones within coverage of KDVN (A), KILX (B), KLOT (C), KLSX (D), and KVWX (E) for Spring 2017. Indices are ranked 1-10 from green to red. 
Figure 8: Detail of Avian Mortality Risk Indices for Previously Studied Towers in Central

Illinois in Fall and Spring
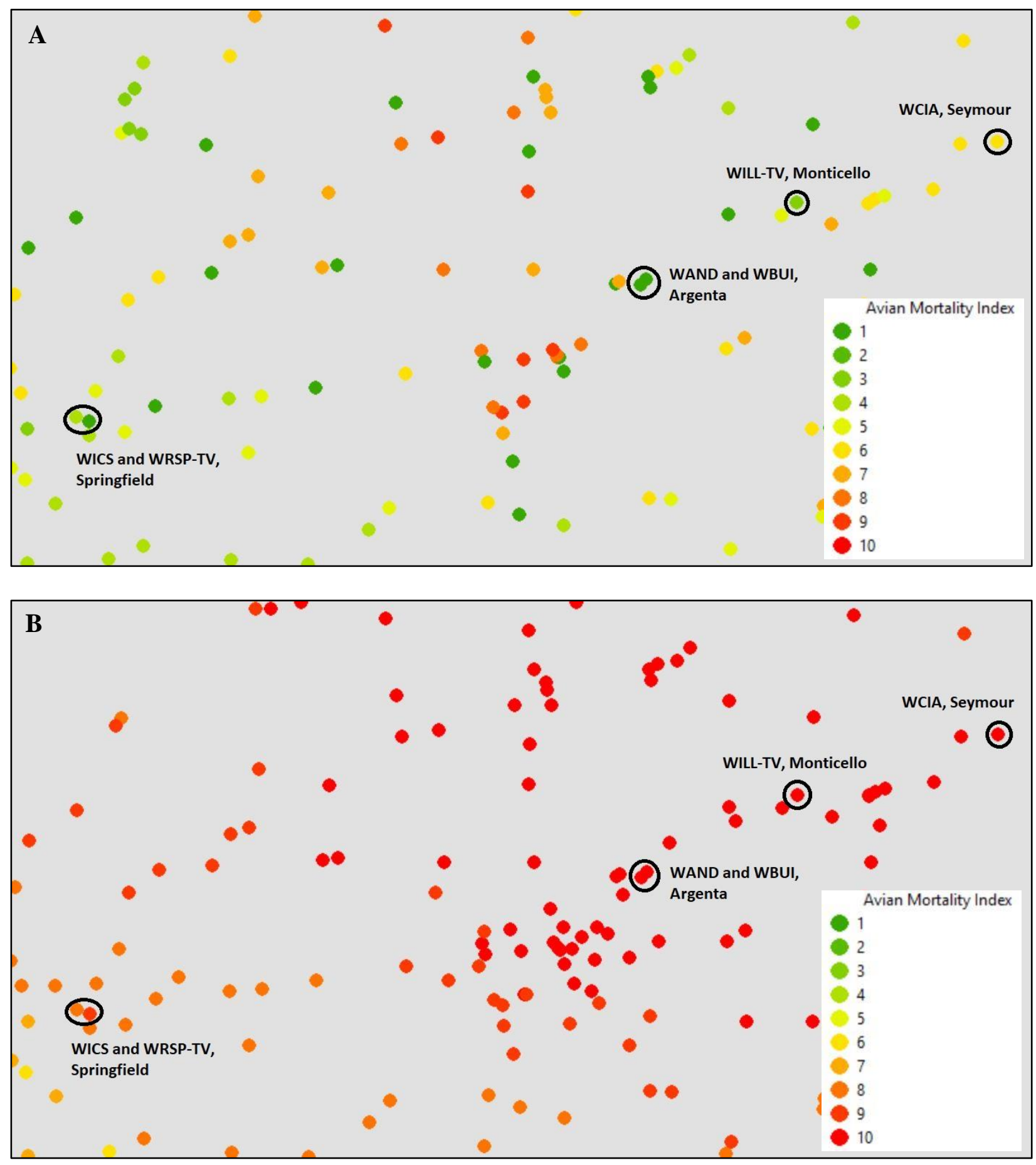
Detail of the central Illinois expanse between Springfield and Champaign showing the avian mortality risk index for six TV towers for Fall 2016 (A) and Spring 2017 (B). Tower height, bird density and light color influenced ranking in the index for fall, and tower height, bird density and average wind speed influenced ranking in the index for spring. Higher values in the wind speed variables resulted in a stronger influence on avian mortality risk in the spring than for tower light color on avian mortality risk in the fall. 

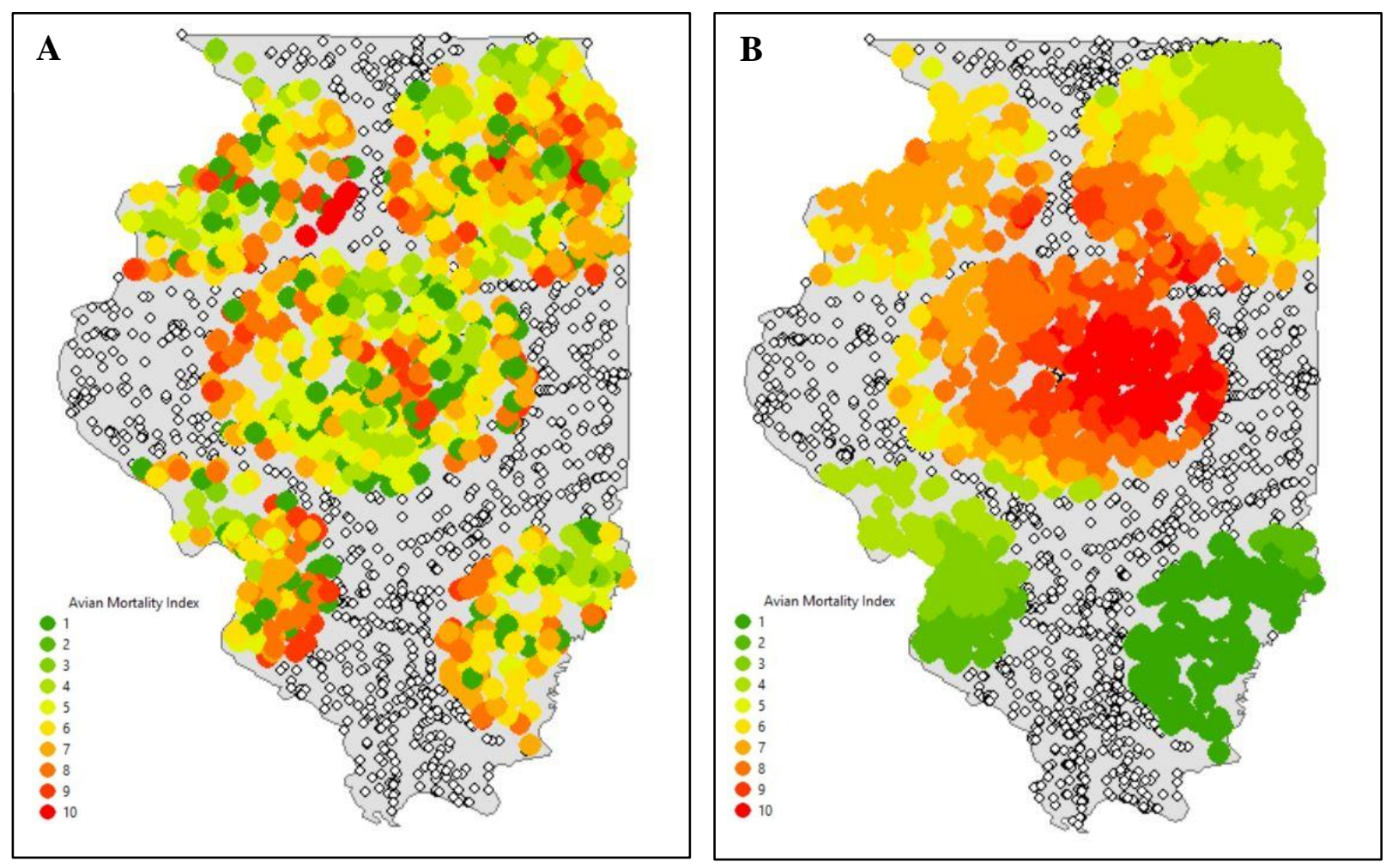

Statewide maps of Illinois comparing indexed towers to data-deficient towers for fall (A) and spring (B). Towers with no avian mortality index are represented with white points. 
Figure 10: Simple Regression of Log-transformed Means for Historic Fall Tower Kills in Illinois and Calculated Values of M.

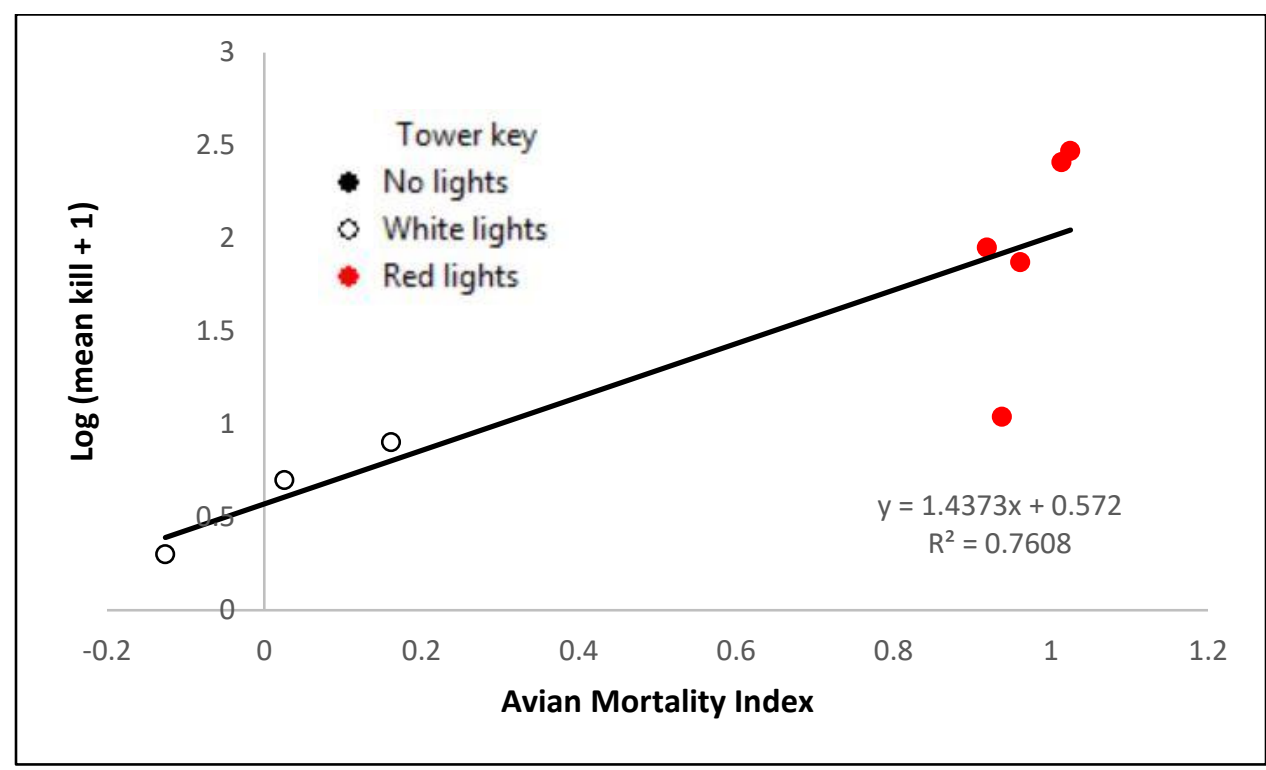

A strong positive correlation indicates a reliable model for measuring the avian mortality risk at previously studied tower sites in Illinois given current tower characteristics. Point color indicates the light color of each tower. 